\title{
Beach surface lost historically: The case of the eastern coast of Las Palmas de Gran Canaria (Canary Islands, Spain)
}

\author{
Eva Pérez-Hernández ${ }^{a, *}$, Aarón M. Santana-Cordero ${ }^{b}$, Luis Hernández-Calvento ${ }^{a}$, \\ María L. Monteiro-Quintana ${ }^{\mathrm{b}}$ \\ ${ }^{a}$ Grupo de Investigación de Geografía Física y Medio Ambiente, Instituto de Oceanografía y Cambio Global, IOCAG, Universidad de Las Palmas de Gran Canaria, Unidad \\ Asociada ULPGC-CSIC, Parque Científico Tecnológico Marino de Taliarte, S/n, 35214, Telde, Las Palmas, Spain \\ ${ }^{\mathrm{b}}$ Research Institute of Text Analysis and Applications (IATEXT), University of Las Palmas de Gran Canaria, C/. Pérez Del Toro, 1, 35003, Las Palmas de Gran Canaria, \\ Canary Islands, Spain
}

\section{A R T I C L E I N F O}

\section{Keywords:}

Coastal transformation

Land cover

Lost beach area

Canary islands

\begin{abstract}
A B S T R A C T
Land use changes cause significant loss of natural and cultural elements. This is the case of the eastern coast of Las Palmas de Gran Canaria (LPGC) (Canary Islands), which was heavily transformed between the late XIX century and the 1960s by increased urban sprawl. Most of the beaches were covered by the city and, therefore, disappeared. The aim of the study is to identify and describe the natural characteristics of the beaches lost between 1879 and 2017 along the eastern coastline of LPGC, as well as to quantify the lost surface area. The changes in land uses that have taken place around these beaches are also addressed. For these purposes, historical sources (documentary, graphic, cartographic and oral) and geographic information systems (GIS) have been used. The results show that, since 1879, eleven beaches, with an extension of 13.19 ha, have disappeared and, with them, their natural and cultural features. Eight land uses were identified: fishing, defensive, agriculture, port, industrial, commercial, residential and recreational. It was also found that beaches from the northern and central sectors had more varied uses than those of the southern sector, which tended to be mainly used for fishing. The results are analyzed at both global and local scale. At global scale, different effects of globalization on coastal urban areas are discussed. At local scale, a discussion is undertaken on how the knowledge acquired can be used to improve future urban planning and to rebuild the memory of the city's coast for its inhabitants and visitors.
\end{abstract}

\section{Introduction}

Coastal lands are areas with numerous natural and strategic values that have long attracted human populations, especially since the mid-XX century (Martínez et al., 2007; Ariza, 2011). Currently, 50-70\% of the global population is concentrated in such areas (Mimura et al., 2007) and nearly $30 \%$ of coastal land has been altered as the result of human activities (Martínez et al., 2007; Ferrer Valero et al., 2017). Land use development and human activities have triggered an important littoralisation process, leading to significant changes to the coast (Lin, 1996; Bajocco et al., 2012) and, in some cases, to the disappearance of previous land cover over entire coastal stretches (Santana Cordero et al., 2014). Coasts are dynamic, complex systems and their features are constantly changing because of both natural and human factors (Kurt et al., 2010; Ponte Lira et al. (2016)). The natural processes that induce such changes include, amongst others, sea level variations due to global warming, wave climate alterations and coastal drift (Schnack et al., 2002; Caires et al., 2006; Stanica and Ungureanu, 2010; Hemer et al., 2013; IPCC, 2014; Dabrio and Polo, 2015; Johnson et al., 2015; Preston et al., 2018; Glavovic et al., 2019). The transformations to them that human activities can result in are, in many cases, irreparable. One of the most damaging activities for these areas has been urban expansion and, since the mid-XX century, the growth of tourism (Nordstrom, 1994; Gormsen, 1997; El Banna and Frihy, 2009; Kiss et al., 2009; Dawson and Smithers, 2010; Kurt et al., 2010; Bochev van der Burgh et al., 2011; Jackson and Nordstrom, 2011; Bajocco et al., 2012; Hepcan et al., 2013; Flor-Blanco et al., 2013; Malavasi et al., 2013). Residential use, port and tourist infrastructures, and recreational activities place great pressure

\footnotetext{
* Corresponding author. Calvento), marialuisa.monteiro@ulpgc.es (M.L. Monteiro-Quintana).

E-mail addresses: eva.perez@ulpgc.es (E. Pérez-Hernández), aaron.santana@ulpgc.es (A.M. Santana-Cordero), luis.hernandez.calvento@ulpgc.es (L. Hernández- 
on the natural processes (e.g. aeolian transport, sea currents, wind flows) that form the coastal landscape (Faggi and Dadon, 2011). These processes are aggravated in islands, which are especially vulnerable areas due to their more limited and scarce resources (Mimura et al., 2007; Hay, 2013; Santana Cordero et al., 2016 Ferrer Valero et al., 2017).

A clear example of these changes induced by human activities can be found on the eastern coast of Las Palmas de Gran Canaria (LPGC) city (Canary Islands, Spain). The evolution experienced by this city has had important consequences for land use and land cover, with major alterations to the shoreline. This particular stretch of coast has experienced several transformations since the late XIX century, especially in the 1960s, as a consequence of socioeconomic changes (Martín Galán, 1980, 2001; 2007, 2008; 2009; Santana Cordero et al., 2017). Occupation of this zone increased in this latter period due to expansion of the port and road infrastructures, as well as the desire to acquire new land for the construction of buildings. Population growth can be added to the constant modernization of buildings and infrastructures as causes of the transformation of most of this coast. In this process, many natural features were eliminated and, to a large extent, virtually forgotten about.

In view of all the above, in this research work we consider the following questions: How was this coast before its transformation? What were the uses and functions of the beaches? How much of the original beach area has been lost?
To answer these questions, we undertook a historical reconstruction of the changes that have taken place, defining what this coastal area was like in terms of its natural features and determining its previous uses and functions. Research studies of this type has been taking place for roughly four decades for various kinds of environment which have experienced historical changes due to the development of human activities (Bürgi and Gimmi, 2007; Grossinger et al., 2007; Hoffman and Rohde, 2007; Ouzts, 2007; McAllister, 2008; Stäuble et al., 2008; Bator, 2009; Gautreau, 2010; McLeman et al., 2010; Stein et al., 2010; Jackson and Nordstrom, 2011; Bajocco et al., 2012; Roig Munar et al., 2012; Ponte Lira et al. (2016); Santana Cordero et al., 2016).

In this kind of research, historic sources, in addition to others, geographic and bibliographic, are of primary importance to enable an accurate reconstruction of the processes that have taken place. Precisely because this type of research works with historic sources, these studies are frequently faced with the difficulty of finding detailed information as, in many cases, there are no written or graphic records of the elements or events that are of interest for the study. For these reasons, oral sources can be essential for the reconstruction of recent events (to around 50 years ago), enabling information obtained from other sources to be contrasted as well as providing new data (Sloan, 2008; Hernández Calvento et al., 2013).

Given these observations and in accordance with the aforementioned research questions, the general aim of this paper is to identify and
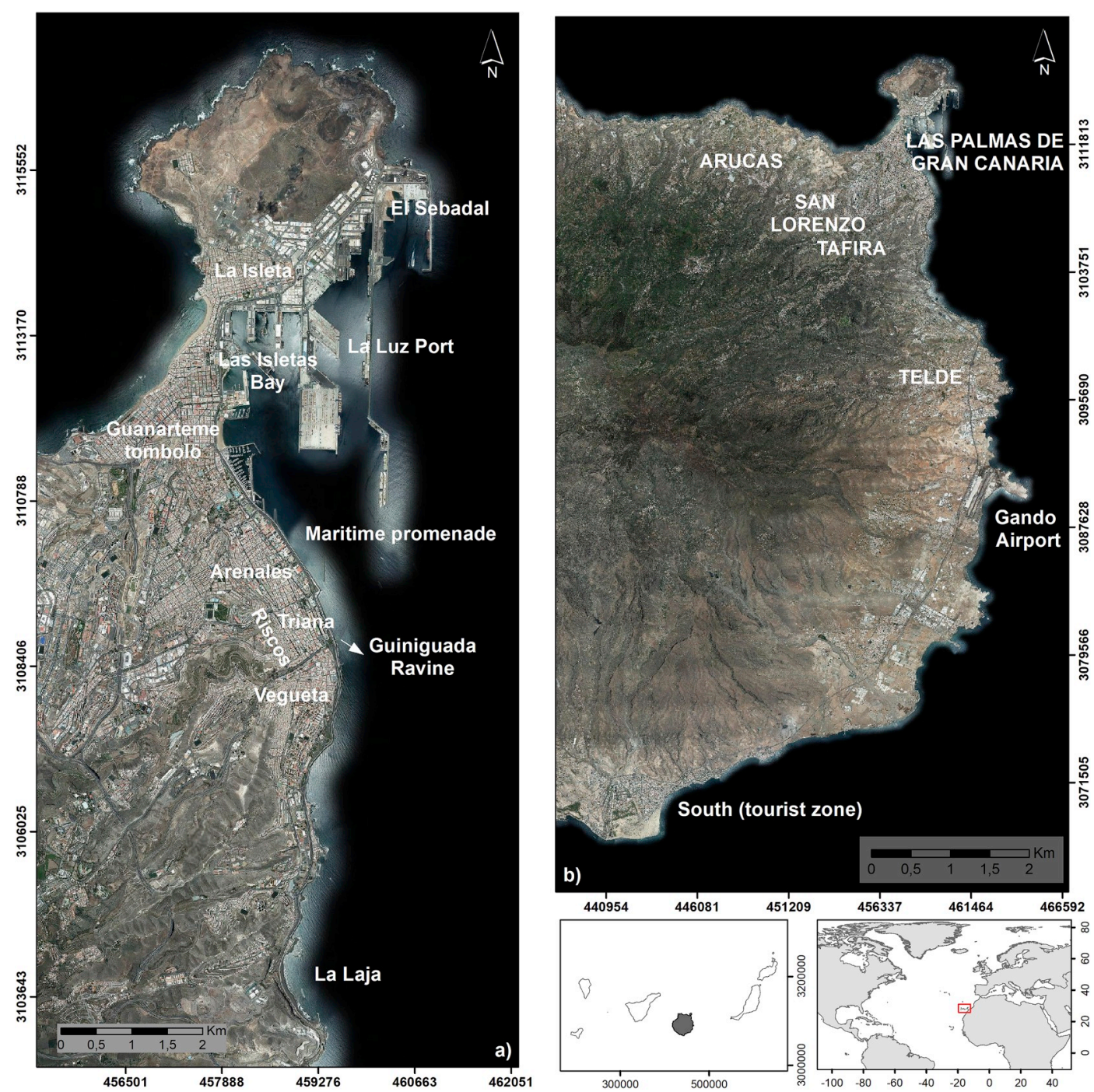

Fig. 1. a) Study area; b) Partial maps of Gran Canaria with main place names cited in the historic context. 
describe the natural beaches that existed along the eastern coast of LPGC before the expansion of the city over this stretch of coast. In line with this general aim, the specific objectives of this study are: (1) to identify and characterise the nature, land uses, functions and cultural traits of the natural beaches of the eastern coast and their changes over time; and (2) to quantify the lost beach area and now-disappeared land cover.

\section{Study area}

The city of LPGC is located in the NE of Gran Canaria island (Canary Islands, Spain). This study focuses on the eastern coastline of LPGC, from the beach of El Sebadal (in the north) to that of La Laja (in the south). The length of the studied shoreline is $19.74 \mathrm{~km}$ and the total area is 16.35 ha (Fig. 1).

From a geological point of view, the northern sector overlies Cycle III lava flows (less than $2 \mathrm{Ma}$ ) and a geological layer called Terraza Baja de Las Palmas (Lower Terrace of Las Palmas), a narrow sedimentary coastal platform that has fossiliferous marine deposits containing Strombus bubonius and Thais haemastoma (Linné), typically found today in warmer climate zones of equatorial Africa (IGME, 1990). This sector of the eastern coast of LPGC was characterized by organic sand beaches of the dune system located on the Guanarteme isthmus. Further south, the geological setting changes: lava flows appear, one from the first volcanic period (14-8 Ma) and another, further south again, from the second one (about $5 \mathrm{Ma}$ ). Consequently, towards the south, the coast was mainly formed by rolling stone beaches with abundant beachrock. At low tide, wide surfaces of dark sand (due to the dominance of volcanic materials) would be revealed (Pérez Hernández and Hernández Calvento, 2017). From an ecological point of view, the vegetation in the study area is disperse and scarce. The species found include Traganum moquinii, Zygophyllum fontanesii, Lotus kunkelii (endemic species), Euphorbia paralias, Cyperus laevigatus, Polycarpaea nivea, Schizogyne sericea and Astydamia latifolia (Banco de Datos de Biodiversidad de Canarias, 2016; GEVIC, 2016). Additionally, in the sea were abundant algae and Cymodocea nodosa, among others (Banco de Datos de Biodiversidad de Canarias, 2016; GEVIC, 2016). Avifauna, including Alcaraván (Burhinus oedicnemus distinctus) and other migratory birds, and marine fauna associated with no longer existing reefs were also found in this area.

The city of LPGC was founded by Spanish conquerors in 1478 in the area now known as Vegueta. The city gradually began to spread in the direction of the Guiniguada ravine. A commercial district named Triana became established as the result of slow but continuous growth which continued to the late XVI century (Martín Galán, 1980). In this phase, the city was walled, forming the historical perimeter of the city which was then comprised of the areas or districts of Vegueta and Triana. In the following two centuries, there were no important changes to the urban fabric of the city, except for the emergence of the first suburbs, called 'riscos' (this term, "cliffs" in English, refers to neighborhoods built on the slopes of the ravines and the high marine terrace), inhabited by the most disadvantaged classes.

Towards the end of the XVIII century, with the expansion of foreign trade and a modernizing impulse in line with the ideas of the Enlightenment, the city partly changed its physiognomy, although it continued to be comprised of the same districts.

In the XIX century, an expansion of the city took place following access routes that connected the city with other inland towns: to the south with Telde, to the west with Tafira and San Lorenzo, and to the northwest with Arucas (Martín Galán, 1980). This stage concluded in 1883 when construction of the port of Las Palmas, Puerto de (Refugio de) La Luz, began. In the mid-XIX century, the collapse of the northern walls took place in the direction of the future port, with a new district emerging (Arenales) from 1858 onwards. The construction of the port saw the city experience a major transformation (Santana Cordero et al., 2016). The resulting significant changes to its physiognomy saw the appearance of Guanarteme district on the tombolo between the city and La Isleta (Martín Galán, 1980). Conurbation between the original city and the port thus began to take place. In the period 1877-1930, the city population grew from 20,756 to 78,214 inhabitants (Noreña Salto and Pérez García (1992)) as people from the inland regions of the island, and from Lanzarote and Fuerteventura, came to the new city neighborhoods. This rise in population resulted in increased urban functionality and a growth in port activity.

For the Canary Islands as a whole, the 1960s saw the commencement of the mass-tourism industry, especially in Gran Canaria and Tenerife. Tourism became the economic growth engine of these islands, triggering a transformation from an agriculture-based to a tourism-based socioeconomic system (Santana Cordero et al., 2017). Construction, transport, and tourism with its associated services were the main lines of development of the Canary Island economy. In Gran Canaria, tourism was developed mainly in the south of the island, exploiting its exceptional climate and the presence of sandy beaches. In this context, the rapid growth in airline connections with different European cities made Gran Canaria airport and the roads that connected it the main development axes of the island.

In this context, port extensions developed eastwards, occupying the south coast of La Isleta and leaving free almost all the coastal front, except for a marina constructed beside Las Alcaravaneras (Martín Galán, 2008). The city continued to grow. In the 1960s and 1970s, the most notable urban interventions were the spread of Triana district towards the coast (CIDELMAR project drawn up by Secundino Zuazo in 1962), the "Plan Parcial del Paseo Marítimo" from 1964, and the development of the highway to the south of the island (Machín Gil and Ruiz-Sánchez (2006)) which also involved construction of a $7 \mathrm{~km}$ long coastal road in Las Palmas. Through these projects, some $250 \mathrm{~m}$ were gained in the direction of the sea, using the former harbor of Las Palmas as a limit of the expansion towards the north.

In short, the fact that space had to be gained from the sea along the eastern coast was due to the need to build a new, wide-gauge road that would facilitate the transport of goods and passengers along the eastern axis of the island, joining the main port (La Luz, in LPGC), the airport and the new tourist areas in the south of the island (Martín Galán, 2008). However, this new road could not cross the tombolo of Guanarteme which, along with its dune system, had disappeared by this time and had been fully built over (Santana Cordero et al., 2014, 2016). The option of building this new highway along the west coast, after circling the city, was not an option either due to the economic interests of the concentrated urban-tourism development that had taken place in the area, with the construction of numerous hotels, apartments and residences, as well as the presence of Las Canteras, one of the island's longest and most impressive sand beaches (Di Paola et al., 2018).

\section{Materials and methods}

Bibliographic references from scientific articles and local publications on the study area - particularly those of Martín Galán (2001, 2007, 2008 , 2009) - were an important resource for this work. Also important were various historical maps, most notably the 1879 Plano de la Bahía de Las Palmas (Map of the Bay of Las Palmas) which shows the coastline before the rapid growth of urban expansion, and 3 maps of different dates (Plano de la ciudad de Las Palmas and Plano del ensanche del Puerto de la Luz by Fernando Navarro and Plano de Las Palmas by Benito Chías Carbó) (details in Table 1), contained in the map collection of Tous and Herrera (1995). These cartographic documents enabled the identification of natural coastal heritage sites (beaches) as well as the toponymical names used at the beginning of the XX century. Current maps were also used, including the geologic map consulted using the SDI (spatial data infrastructure) of the Canary Islands (Grafcan, S.A. - Government of the Canary Islands), the geologic map of LPGC and Santa Brígida (scale: 1: 25,000), from the Instituto Tecnológico Geominero de España (Geological and Mining Institute of Spain) and Google Earth.

Aerial photographs from 1954, acquired from the Centro Cartográfico y Fotográfico del Ejército del Aire de España (Cartography and 
Table 1

Characteristics of historic maps and other cartographic documents.

\begin{tabular}{|c|c|c|c|c|}
\hline Date & Document type/title & $\begin{array}{l}\text { Scale/ } \\
\text { resolution }\end{array}$ & Producer & References \\
\hline 1879 & $\begin{array}{l}\text { Plano de la bahía de } \\
\text { Las Palmas }\end{array}$ & $1: 20000$ & $\begin{array}{l}\text { Directorate of } \\
\text { Hydrography }\end{array}$ & $\begin{array}{l}\text { Tous and } \\
\text { Herrera } \\
\text { (1995) }\end{array}$ \\
\hline 1910 & $\begin{array}{l}\text { Plano de la ciudad de } \\
\text { Las Palmas }\end{array}$ & $1: 5000$ & $\begin{array}{l}\text { Fernando } \\
\text { Navarro }\end{array}$ & $\begin{array}{l}\text { Tous and } \\
\text { Herrera } \\
\text { (1995) }\end{array}$ \\
\hline 1910 & $\begin{array}{l}\text { Plano del ensanche } \\
\text { del Puerto de la Luz }\end{array}$ & $1: 5000$ & $\begin{array}{l}\text { Fernando } \\
\text { Navarro }\end{array}$ & $\begin{array}{l}\text { Tous and } \\
\text { Herrera } \\
(1995)\end{array}$ \\
\hline 1914 & Plano de Las Palmas & 1:13000 & $\begin{array}{l}\text { Benito Chías } \\
\text { Carbó }\end{array}$ & $\begin{array}{l}\text { Tous and } \\
\text { Herrera } \\
(1995)\end{array}$ \\
\hline 1990 & $\begin{array}{l}\text { Geologic map (Las } \\
\text { Palmas de Gran } \\
\text { Canaria and Santa } \\
\text { Brígida) }\end{array}$ & $1: 50000$ & $\begin{array}{l}\text { Geological and } \\
\text { Mining Institute } \\
\text { of Spain }\end{array}$ & IGME (1990) \\
\hline 2010 & Geologic map & $1: 50000$ & $\begin{array}{l}\text { SDI of the Canary } \\
\text { Islands }\end{array}$ & $\begin{array}{l}\text { IDECanarias } \\
\text { (2018) }\end{array}$ \\
\hline 1954 & Aerial photographs & $1: 2650$ & CECAF & CECAF (1954) \\
\hline 1966 & Orthophoto & $1: 7000$ & $\begin{array}{l}\text { SDI of the Canary } \\
\text { Islands }\end{array}$ & $\begin{array}{l}\text { IDECanarias } \\
(2018)\end{array}$ \\
\hline 2017 & Orthophoto & $\begin{array}{l}25 \mathrm{~cm} / \\
\text { pixel }\end{array}$ & $\begin{array}{l}\text { SDI of the Canary } \\
\text { Islands }\end{array}$ & $\begin{array}{l}\text { IDECanarias } \\
(2018)\end{array}$ \\
\hline
\end{tabular}

Photography Centre of the Air Force of Spain) (CECAF, 1954), were used to enable identification and mapping of the areas of interest, as well as two orthophotos from 1966 to 2017.

Several pictures were consulted from the FEDAC catalogue (Fundación para la Etnografía y el Desarrollo de la Artesanía Canaria Foundation for Ethnography and the Development of Canarian Crafts, 2015), as well as the websites Las Palmas Ayer y Hoy (2018), Recuerdos de Gran Canaria (2018) and Gran Canaria. imágenes del ayer (2018) (unpublished images). These were used to identify specific elements in the territory from the late XIX century to the 1970s.

Fieldwork was also performed to collect oral sources. A total of nine interviews were conducted with a group of people who were born between 1919 and 1953. The selection of the people who were interviewed was based on two criteria: (1) people who lived close to the city coast before its transformation; and (2) distribution over the three sectors of the coast which formed the area of study in this work ( 3 in the northern sector; 5 in the central sector and 1 in the southern sector). The interviews, carried out in 2015 between March and May, allowed information gaps to be filled and information obtained from other sources to be contrasted. The interview comprised a semi-structured conversation between two people (interviewer and narrator) (Fogerty, 2005) in which different resources were used to correctly identify the natural heritage, including a guide with a series of open and closed questions (Fig. 2), a tape recorder and historic photographs.

The information obtained was integrated into a GIS, which allowed us to locate all elements of interest on the aerial photograph from 1954 and the current orthophoto (2017). In doing so, it was necessary to geometrically correct the 1954 aerial photographs. This allowed us to detect and show the coastal changes between 1954 and 2017, using the wet mark to digitalize the shorelines (Ojeda Zújar (2000)) and calculate the dry beach areas. The two documents were compared to determine which of the studied places no longer existed. Finally, this process enabled a calculation of the so-called lost heritage.

Notwithstanding the above, it should be acknowledged that the two documents contained a series of errors due to both the geometric adjustment and digitalization processes. These errors (Table 2) were calculated following Robinson et al. (1987) and García Romero et al. (2016). It should also be noted that there may be some temporal variation in the coastline, because the tidal range in the study area is about

Table 2

Geometric adjustment and delineation errors.

\begin{tabular}{lll}
\hline Document type & RMS (m) & Error delineation (m) \\
\hline Orthophoto (2017) & $<1.5 \mathrm{~m}$ & $1 \mathrm{~m}$ \\
Aerial photographs (1954) & $3 \mathrm{~m}$ (max.) & $0.54 \mathrm{~m}$ \\
\hline
\end{tabular}

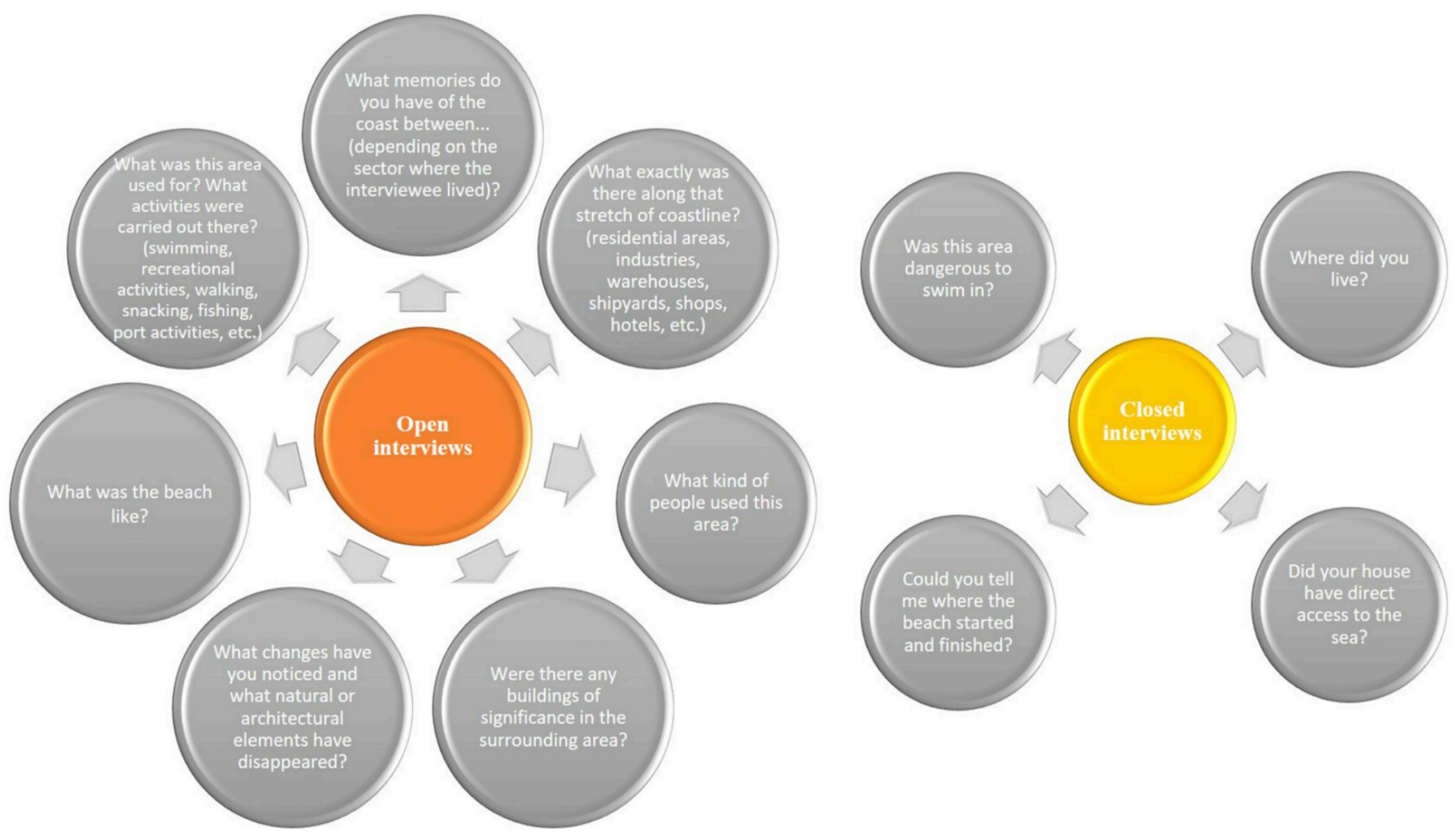

Fig. 2. Type of question asked during the interviews. 
$3 \mathrm{~m}$ maximum. However, the fact that, in general, the coast in the study area is reflective and presents a rocky basement minimizes the effect of the tidal range. In any case, the accumulated values of these errors are lower than the changes produced in the coastline by urban expansion, some $250 \mathrm{~m}$, as previously mentioned in the Study Area section.

\section{Results}

\subsection{Beach identification}

The reconstruction made using the historic sources allowed us to identify the existence in 1879 of 14 natural beaches along the eastern coastline of LPGC, and in 1954 of 12 . Of these, only three remain (Fig. 3; Table 3). According to their location and considering the type of geological material, the beaches can be divided into three sectors:
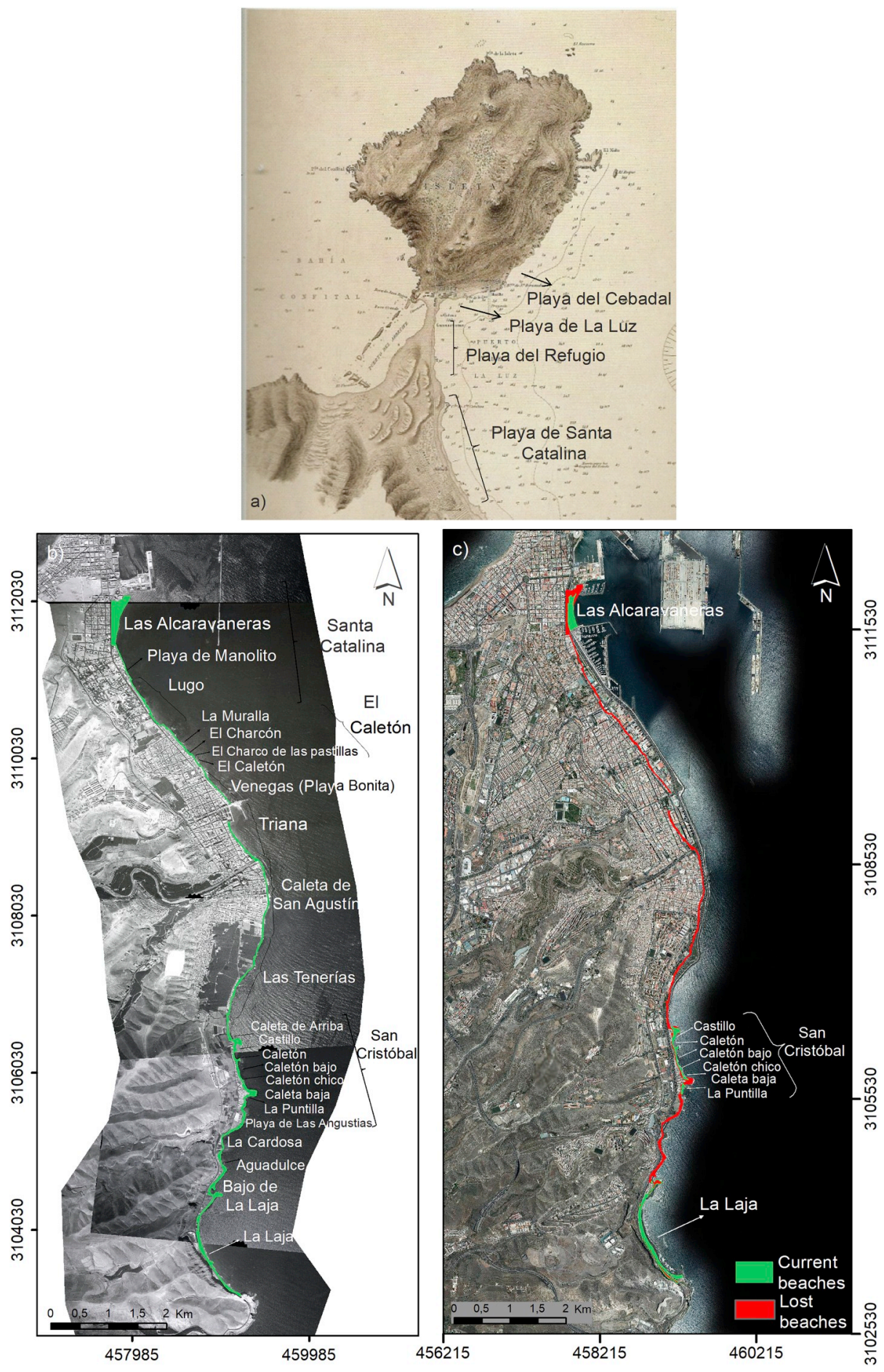

Fig. 3. a) Location of beaches on the 1879 map; b) Location of beaches in 1954; and c) in 2016. From the 1879 map, the first beaches to disappear were due to construction of Puerto de La Luz and the urban growth of the city towards the east. For these reasons, in map b), from the 1954 aerial photograph, the port zone has been excluded since no beach existed there. 
Table 3

Toponymy according to the historical moment (late XIX century, beginning and mid-XX century and current times), and following a north-south direction.

\begin{tabular}{|c|c|c|c|c|c|c|c|c|}
\hline & \multicolumn{2}{|c|}{ End of the XIX century } & \multicolumn{2}{|c|}{ Beginning of the $\mathrm{XX}$ century } & \multicolumn{2}{|c|}{ Middle of the XX century } & \multicolumn{2}{|l|}{ Current } \\
\hline Northern & \multicolumn{2}{|c|}{ Playa del Sebadal } & \multicolumn{2}{|l|}{ - } & & & \multicolumn{2}{|l|}{-} \\
\hline sector & \multicolumn{2}{|c|}{ Playa de La Luz/Playa de Las Isletas } & \multicolumn{2}{|l|}{-} & \multicolumn{2}{|l|}{ _- } & \multicolumn{2}{|l|}{-} \\
\hline & \multicolumn{2}{|c|}{ Playa del Refugio } & \multicolumn{2}{|l|}{-} & \multicolumn{2}{|l|}{-} & \multicolumn{2}{|l|}{-} \\
\hline \multirow[t]{12}{*}{ Central sector } & \multirow{3}{*}{\multicolumn{2}{|c|}{ Playa Santa Catalina }} & \multirow{3}{*}{\multicolumn{2}{|c|}{$\begin{array}{l}\text { Playa Santa Catalina } \\
\text { Playa Las Alcaravaneras } \\
\text { Playa de Lugo }\end{array}$}} & \multicolumn{2}{|c|}{ Playa Las Alcaravaneras } & \multicolumn{2}{|c|}{ Playa Las Alcaravaneras } \\
\hline & & & & & Playa de M & & - & \\
\hline & & & & & Playa de Li & & - & \\
\hline & \multirow{6}{*}{\multicolumn{2}{|c|}{ El Caletón }} & \multirow[t]{6}{*}{ El Caletón } & Aguadulce & El Caletón & Aguadulce & - & \\
\hline & & & & La Muralla & & La Muralla & & \\
\hline & & & & El Charco de las & & El Charco de las & & \\
\hline & & & & Pastillas & & Pastillas & & \\
\hline & & & & El Charcón & & El Charcón & & \\
\hline & & & & El Caletón & & El Caletón & & \\
\hline & \multirow{3}{*}{\multicolumn{2}{|c|}{$\begin{array}{l}\text { San Sebastián/Charcón de Arenales } \\
\text { Playa de Triana/San Telmo } \\
\text { Playa de San Agustín/Caleta de San } \\
\text { Agustín }\end{array}$}} & \multirow{3}{*}{\multicolumn{2}{|c|}{$\begin{array}{l}\text { Playa Bonita/Venegas } \\
\text { Playa de Triana } \\
\text { Playa de San Agustín }\end{array}$}} & \multicolumn{2}{|c|}{ Playa Bonita/Venegas } & \multicolumn{2}{|l|}{ - } \\
\hline & & & & & Playa de $\mathrm{T}$ & /La Marina & - & \\
\hline & & & & & Playa de S & gustín & - & \\
\hline \multirow{14}{*}{$\begin{array}{l}\text { Southern } \\
\text { sector }\end{array}$} & \multicolumn{2}{|c|}{ Playa de las Tenerías } & \multicolumn{2}{|c|}{ Playa de las Tenerías } & Playa de la & herías & - & \\
\hline & San & Caleta de Arriba & San & Caleta de Arriba & San & Caleta de Arriba & San & - \\
\hline & Cristóbal & Castillo & Cristóbal & Castillo & Cristóbal & Castillo & Cristóbal & Castillo \\
\hline & & Caletón & & Caletón & & Caletón & & Caletón \\
\hline & & Caletón Chico & & Caletón Chico & & Caletón Chico & & $\begin{array}{l}\text { Caletón } \\
\text { Chico }\end{array}$ \\
\hline & & Caletón Bajo & & Caletón Bajo & & Caletón Bajo & & Caletón Bajo \\
\hline & & Caleta Baja & & Caleta Baja & & Caleta Baja & & Caleta Baja \\
\hline & & Puntilla & & Puntilla & & Puntilla & & Puntilla \\
\hline & & Playa de Las & & Playa de Las Angustias & & Playa de Las Angustias & & - \\
\hline & & Angustias & & & & & & \\
\hline & La Cardos & 1 Cardoso & La Cardosa & 1 Cardoso & La Cardosa & 1 Cardoso & - & \\
\hline & Aguadulce & & Aguadulce & & Aguadulce & & - & \\
\hline & Bajo de La & & Bajo de La & & Bajo de La & & - & \\
\hline & $\begin{array}{l}\text { La Laja/C } \\
\text { Laxa }\end{array}$ & de San Sebastián or & La Laja & & La Laja & & La Laja & \\
\hline
\end{tabular}

northern (Sebadal, La Luz and El Refugio); central (Santa CatalinaAlcaravaneras, Lugo, El Caletón, Venegas, Triana and San Agustín) and southern (Las Tenerías, San Cristóbal, La Cardosa, Aguadulce, Bajo de La Laja and La Laja) (Fig. 3; Table 3).

\subsection{Land uses and cultural traits}

The sources consulted revealed that the land uses of this coast were various and evolved progressively in accordance with the growth and modernization of the city (Fig. 4). Before the XIX century, the coast was an uninhabited, marginal and undervalued zone, considered unsafe and unhealthy (Martín Galán, 2008). As such, this zone was configured as an area for defense where agriculture and fishing activities were also undertaken. After work began on the construction of Puerto de la Luz (1883) and with the gradual incorporation of the customs of foreign people who came to visit and live in the islands, this situation began to evolve, the coast started to be revalued and new land uses appeared.

Thus, in this coast we can find eight different land uses (Table 4).

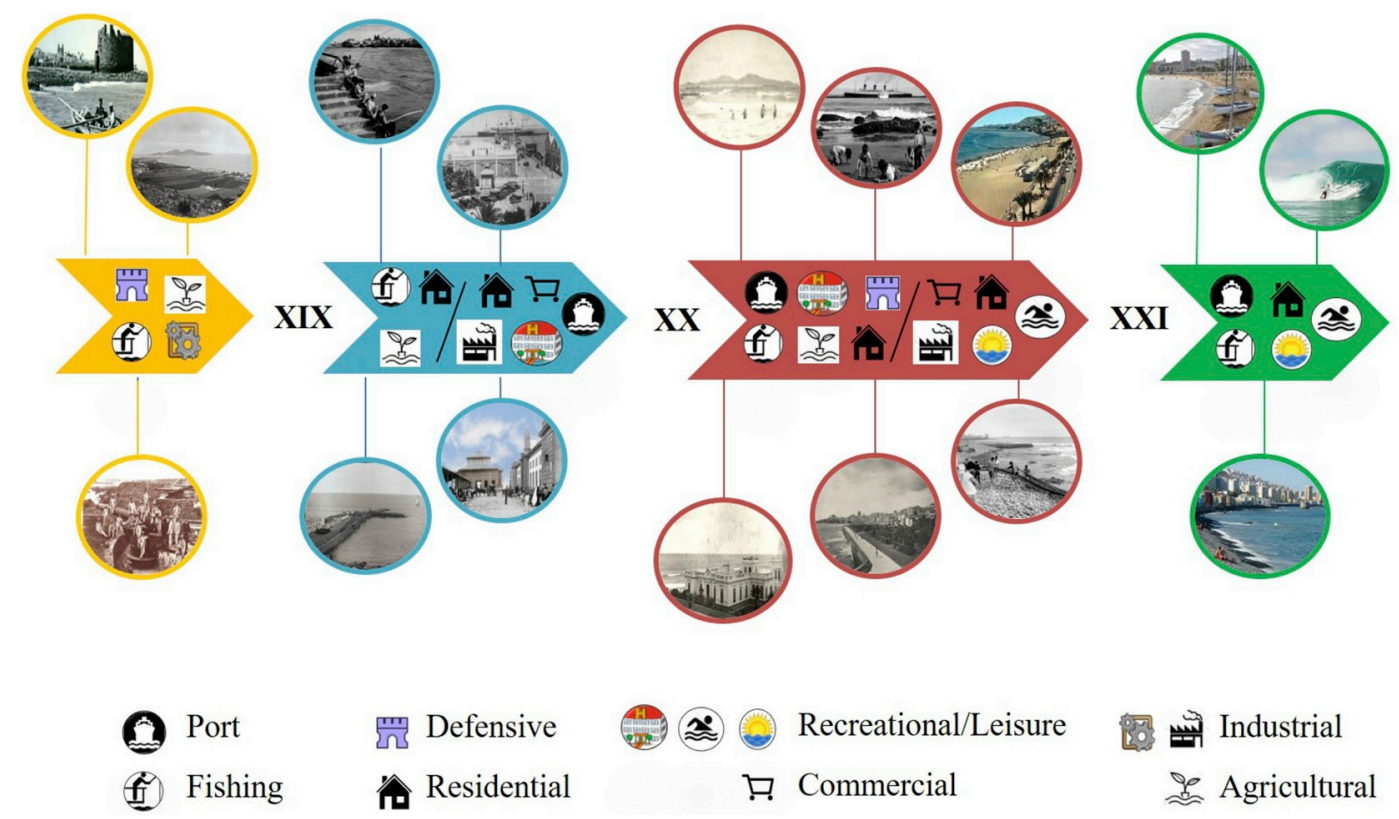

Fig. 4. Evolution of land use along the eastern coast of LPGC (photos: Las Palmas Ayer y Hoy, Recuerdos de Gran Canaria and FEDAC, 2015). 
Table 4

Description of the land uses identified.

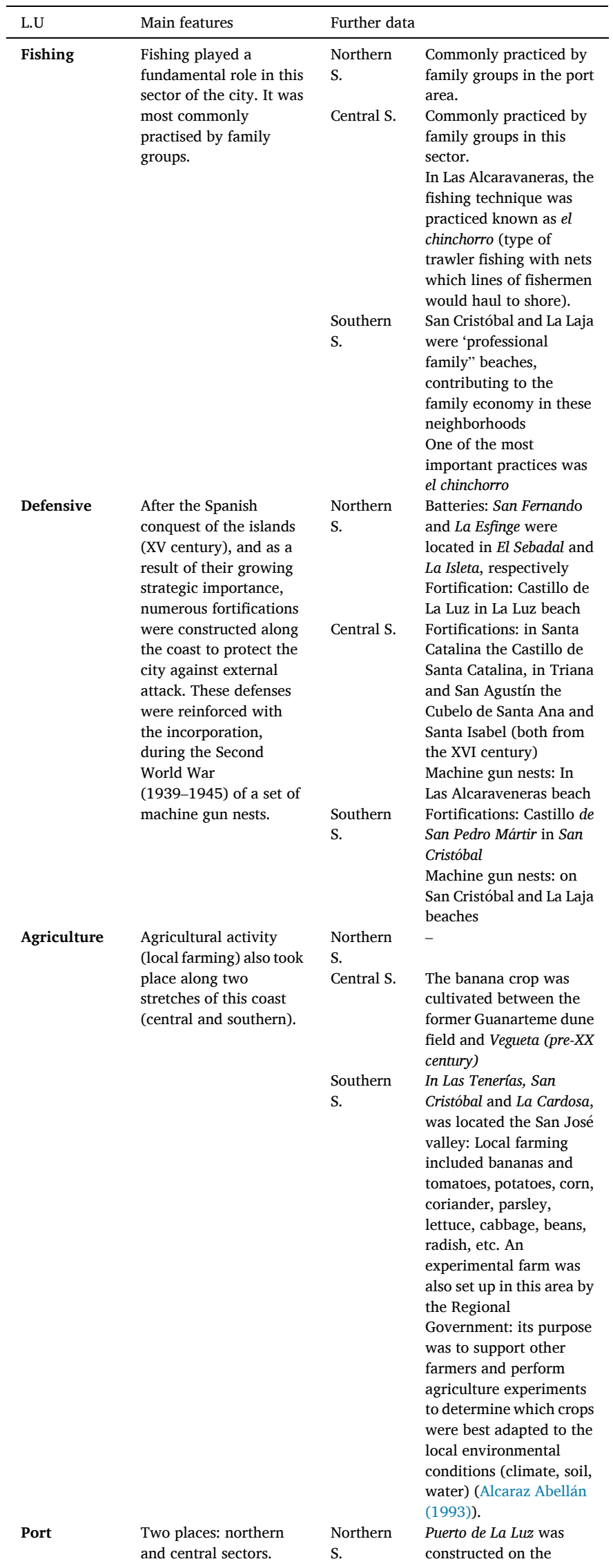

Table 4 (continued)

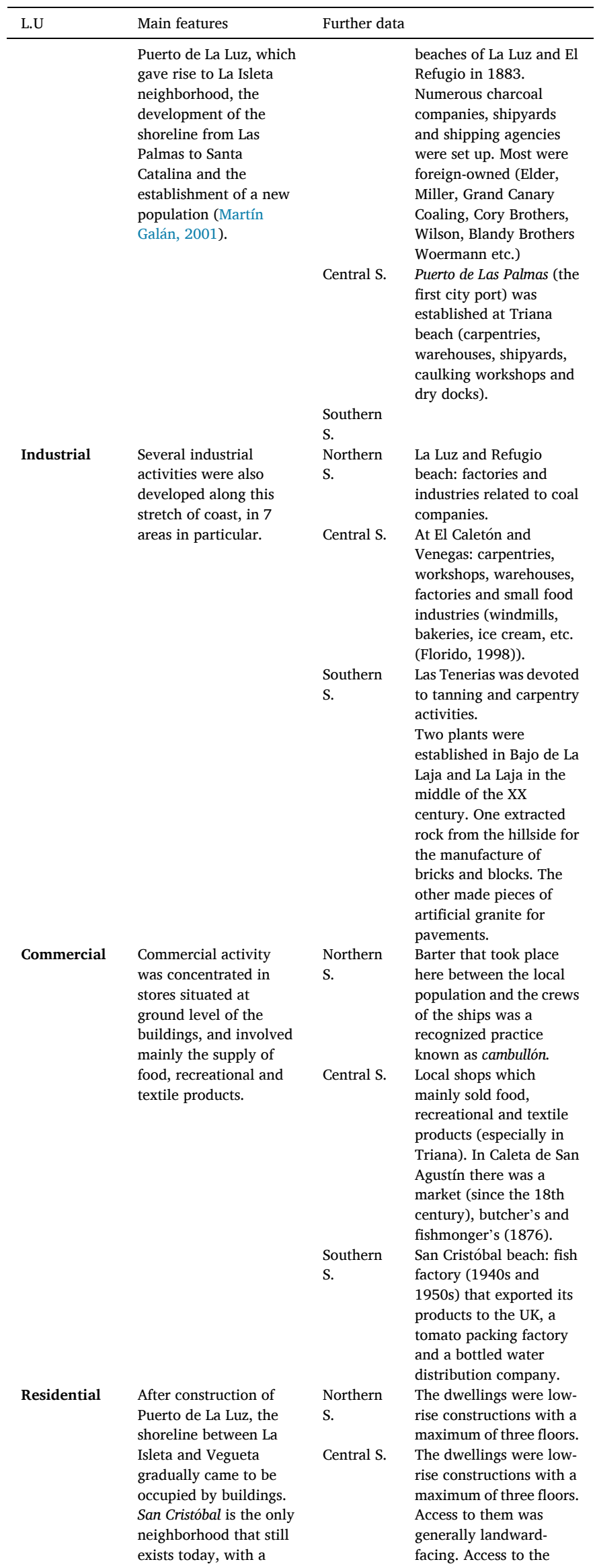

(continued on next page) 
Table 4 (continued)

\begin{tabular}{|c|c|c|c|}
\hline L.U & Main features & Further data & \\
\hline Recreational & $\begin{array}{l}\text { The first recreational } \\
\text { use was for health } \\
\text { tourism (the first tourist } \\
\text { activity in the island) at } \\
\text { the end of the XIX } \\
\text { century. From this time } \\
\text { onwards and with the } \\
\text { introduction of foreign } \\
\text { customs, sea bathing } \\
\text { began to acquire some } \\
\text { popularity among the } \\
\text { local population and the } \\
\text { value of this } \\
\text { environment became } \\
\text { more appreciated ( } \\
\text { Martín Galán, 2009). In } \\
\text { the mid-XX century the } \\
\text { coast became a } \\
\text { recreational area for } \\
\text { walks, contemplation of } \\
\text { the maritime landscape, } \\
\text { sports, games etc. The } \\
\text { children of the poorest } \\
\text { families would } \\
\text { construct their own toys } \\
\text { from waste materials } \\
\text { that arrived at the } \\
\text { beaches. }\end{array}$ & $\begin{array}{l}\text { Northern } \\
\text { S. } \\
\text { Central S. }\end{array}$ & $\begin{array}{l}\text { beach was possible } \\
\text { through a back door or } \\
\text { via small passageways } \\
\text { that separated the } \\
\text { buildings. } \\
\text { The dwellings were self- } \\
\text { constructed with local } \\
\text { materials (soil, loose } \\
\text { material, sand and stone } \\
\text { blocks) (Machín Gil } \\
\text { (2006)). Further south } \\
\text { were relatively } \\
\text { unpopulated sectors. } \\
\text { Near to the port the } \\
\text { departure and arrivals of } \\
\text { the ships constituted an } \\
\text { attraction for the local } \\
\text { population. } \\
\text { Santa Catalina beach } \\
\text { (Las Alcaravaneras): } \\
\text { different hotels and other } \\
\text { tourist facilities were } \\
\text { concentrated here at the } \\
\text { end of the XIX century. In } \\
\text { the } 1950 \text { s, it was one of } \\
\text { the best prepared } \\
\text { beaches for family } \\
\text { activities. A spa, } \\
\text { restaurant, bar and small } \\
\text { boats for short sea trips } \\
\text { could be found here. } \\
\text { Another attraction of this } \\
\text { beach was the sight of } \\
\text { hydroplanes landing on } \\
\text { the sea (Cossío, 2014). } \\
\text { Triana beach had a } \\
\text { promenade and San } \\
\text { Telmo park was nearby ( } \\
\text { Martín Galán, 2008). } \\
\text { Playa de Las Angustias: } \\
\text { Camping with tents often } \\
\text { made by the locals from } \\
\text { old blankets, sheets or } \\
\text { flour and sugar bags. } \\
\text { La Laja beach: people } \\
\text { went there to rest and } \\
\text { snack. Summer houses of } \\
\text { families from Triana and } \\
\text { there found }\end{array}$ \\
\hline
\end{tabular}

Depending on its characteristics and localization, each beach had a different function (Figs. 5-7) for which various land uses were developed.

It can be seen how the northern and central beaches had more varied uses than those of the southern sector which tended to focus on fishing. Land uses were (high to low frequency): fishing, residential, recreational, agriculture, industrial, commercial, defensive and port. Some of these uses were no longer functional over time. Such is the case of the defensive elements located in San Cristóbal and Triana (Torreón de San Pedro Mártir and Cubelo de Santa Ana, respectively), which lost their use after the beginning of the 19th century.

\subsection{Lost surface area}

In terms of surface area, 13.19 ha of beaches have been lost. Currently, the only beaches that remain are Las Alcaravaneras, San Cristóbal, La Laja and Bajo de La Laja (Pérez Hernández and Hernández Calvento, 2017) (Table 5).

Of these, Las Alcaravaneras has been the most affected, losing 3.78 ha due to the development of port infrastructures. Currently, this beach is located within the port area. The beach of San Cristóbal has lost 2.06 ha as the result of construction of the promenade and the small port area in this neighborhood. Bajo de La Laja has almost completely disappeared (0.69 ha lost), whereas La Laja has not experienced major loss (only 0.18 ha). Although San Cristóbal and La Laja have experienced changes, their morphologies have remained more or less unaltered.

The rest of the coast (including the beaches that formed it) disappeared in the mid-XX century due to the extension of the city towards the sea (Fig. 8) and the need to acquire more land for the population. Thus, $100 \%$ of the territory of these beaches was lost.

\subsection{Overview}

In terms of land use, the occupation of the eastern coast of LPGC generally speaking followed three pathways depending on the sector: (1) buildings and infrastructures were located near to the shoreline, but did not significantly affect its characteristics: this was the case in San Cristóbal and La Laja; (2) port infrastructures and buildings altered the morphology of the original shoreline: this was the case in Las Alcaravaneras; and (3) the infrastructures and buildings totally changed the coast: this was the case in El Sebadal, La Luz, El Refugio, Lugo, El Caletón, Venegas, Triana, San Agustín, Las Tenerías, La Cardosa, Aguadulce and Bajo de La Laja.

In general, the northern beaches were occupied by port, commercial and industrial facilities. The growth of the city of LPGC occupied the central sector of this coastal stretch, from Las Alcaravaneras to Vegueta, invading the former Guanarteme dune system (Santana Cordero et al.,

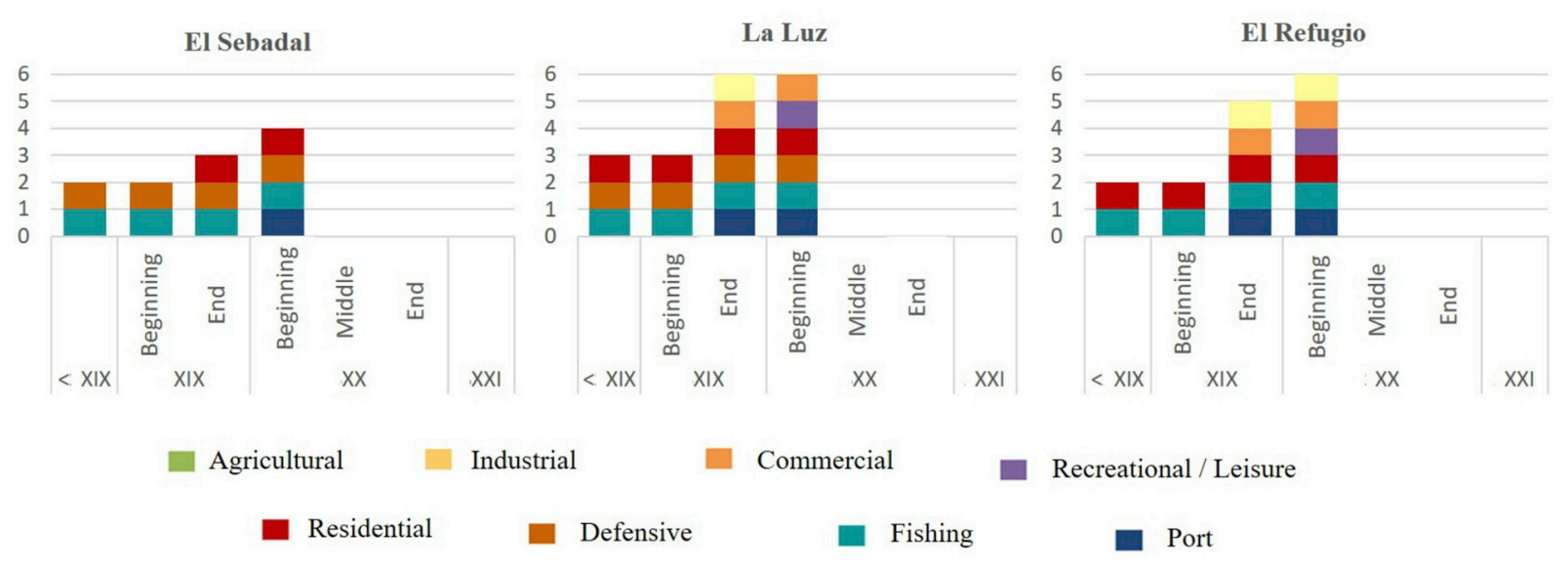

Fig. 5. Distribution of land use by century (pre-XIX century, XIX century, XX century and XXI century) in the northern sector. 

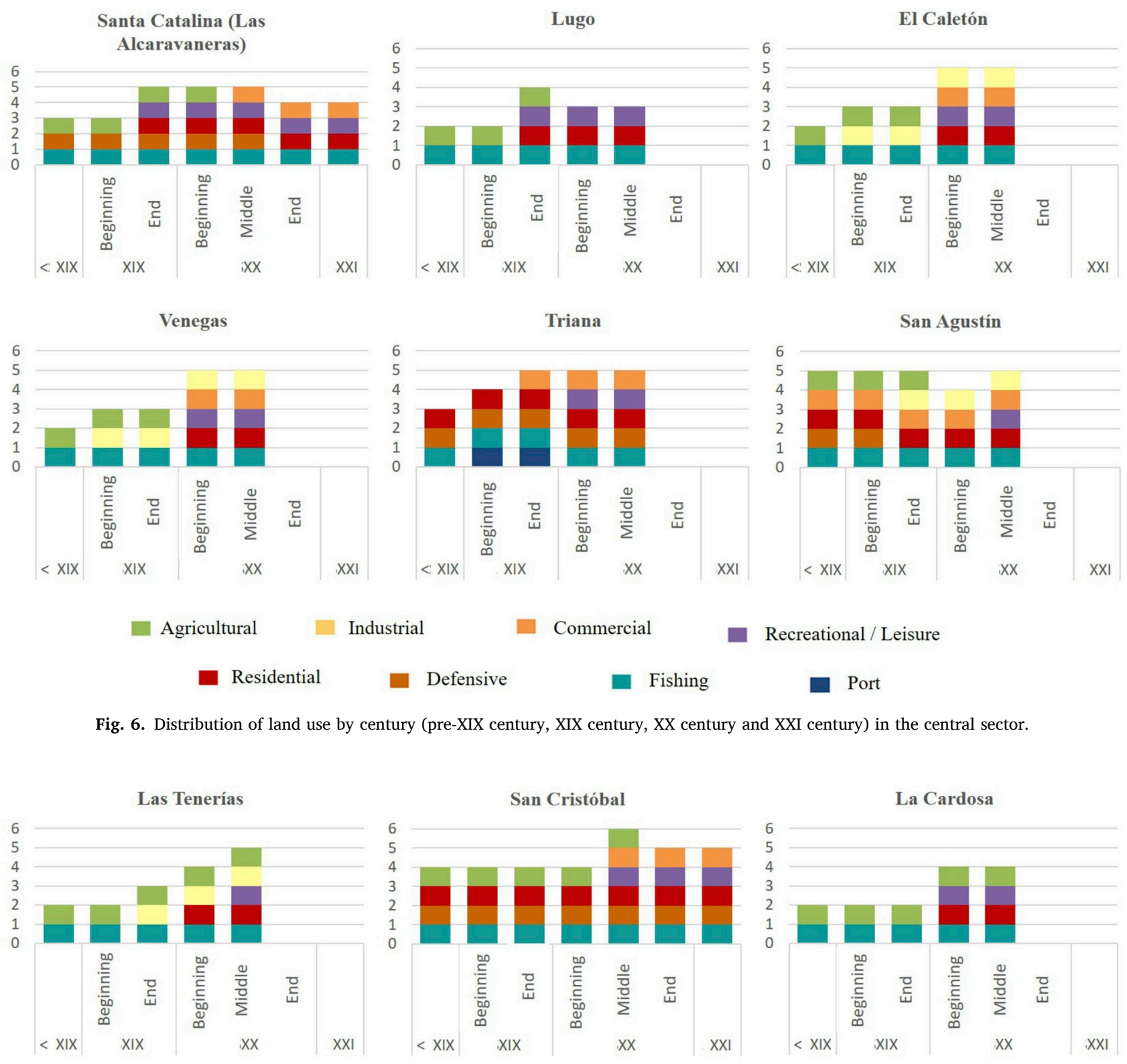

San Agustín 
Table 5

Beaches and their surface area (ha).

\begin{tabular}{lll}
\hline Beaches & Area (ha) 1954 & Area (ha) today \\
\hline El Sebadal & Unknown $^{\mathrm{a}}$ & 0 \\
La Luz & Unknown $^{\mathrm{a}}$ & 0 \\
El Refugio & Unknown $^{\mathrm{a}}$ & 0 \\
Santa Catalina (Las Alcaravaneras and Lugo) & 6.85 & 3.07 \\
El Caletón & 0.77 & 0 \\
Venegas (Playa Bonita) & 0.42 & 0 \\
Triana & 0.91 & 0 \\
San Agustín & 1.13 & 0 \\
Las Tenerías & 1.59 & 0 \\
San Cristóbal & 3.83 & 1.77 \\
La Cardosa (El Cardoso) & 0.68 & 0 \\
Aguadulce & 0.97 & 0 \\
Bajo de La Laja & 0.71 & 0.02 \\
La Laja & 3.57 & 3.39 \\
\hline
\end{tabular}

a Note that El Sebadal, La Luz and El Refugio beaches cannot be mapped (nor therefore their areas measured) from the 1954 aerial photograph, because at the time they did not exist. These beaches were identified from historical maps and oral sources.
2014, 2016, 2017). The southern coast was occupied by road and health infrastructures, residential zones and green spaces.

Bearing in mind these three modalities of occupation, the characteristics of each stretch of the coast are presented in Tables 6-8.

\section{Discussion}

Coastal areas have become places of growing interest in the scientific literature (Gormsen, 1997; Martínez et al., 2007). As has been demonstrated, they are areas which are highly susceptible to change in terms of their morphological dynamics, with significant natural losses occurring as a result of human activities (Jackson and Nordstrom, 2011; García Romero et al., 2016). It is widely accepted that such consequences can derive from the processes involved in changes to land use. This has been the case of our study area. The present work has shown not only the evolution and transformations experienced by this coast, but also the territorial and functional losses that it has undergone by linking disappeared beaches with those existing in the present. Additionally, this research provides quantitative data with which the natural losses can be calculated.

The study area has undergone major changes, especially in relation

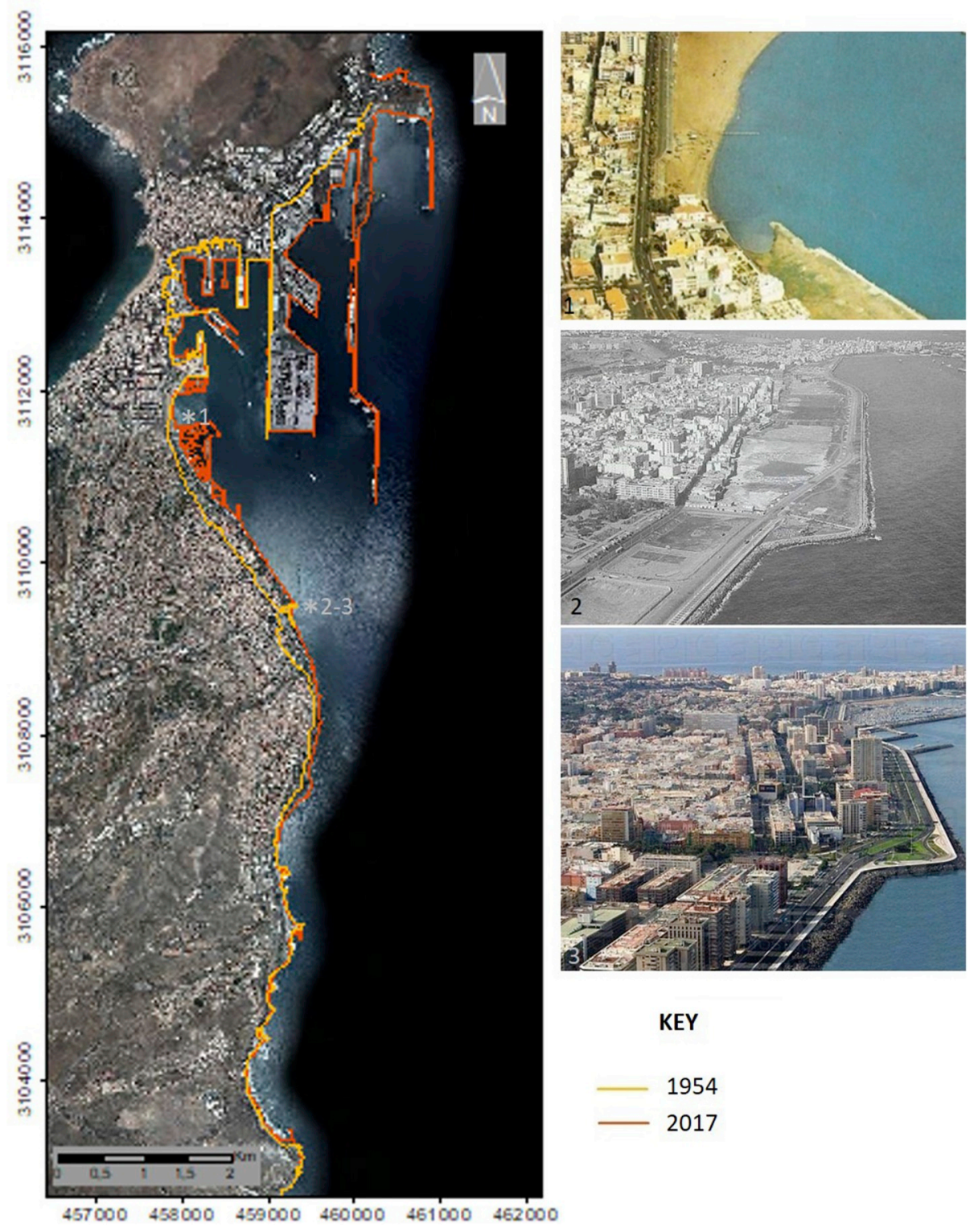

Fig. 8. Comparison of the shoreline in 1954 and in 2017. Photos: IDECanarias, Las Palmas Ayer y Hoy and Recuerdos de GC. 
Table 6

Natural and cultural characteristics, land use and lost area of the beaches of the northern sector of the eastern coast of LPGC.

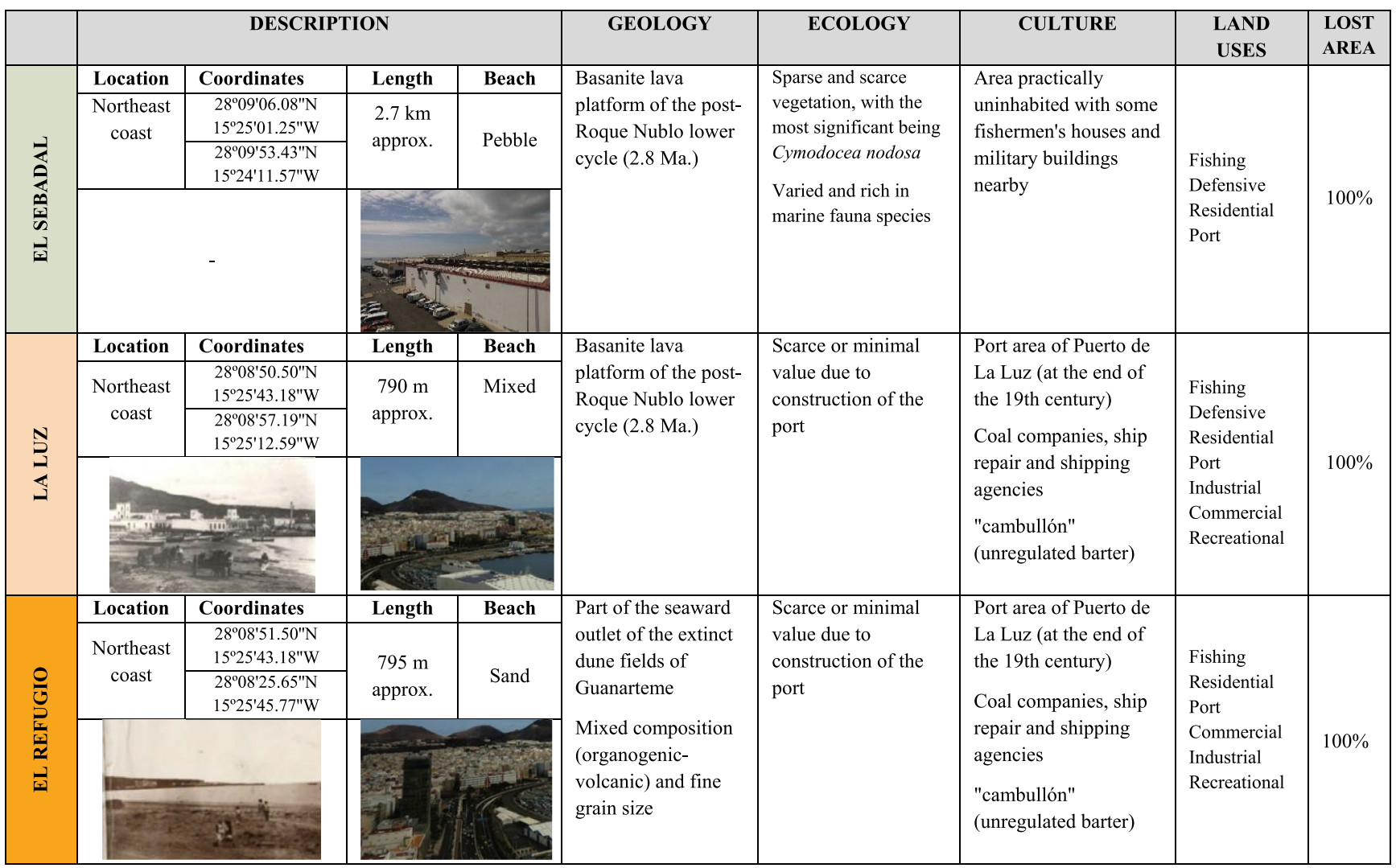

to land use and the natural landscape. The results show that most of the eastern coast of LPGC has been lost, with only some sections of three beaches remaining intact: Las Alcaravaneras, San Cristóbal and La Laja. We consider that exogenous socio-economic factors (Lambin and Meyfroidt, 2010), above all with respect to the influence of the port and the investments it has attracted, are the main cause of land change and transformation in this general area. Other factors include the rush to 'modernize' the city, urbanistic/political motives driven by the needs of a growing population, and the substantially lower environmental awareness that existed in the past. By way of example, a City Project document from 1894 (Archivo Histórico Nacional, 1894) explains how the plan to gain land from the sea along the Santa Catalina beaches was a viable and cheap option given that other land was being used at the time for crops and, as the document claims, "the coast has no value for society". Consequently, important resources, from a social and land use point of view, have been lost to the city. The local establishment of a given land use is usually linked to cultural traits that characterizes the area. In this line, traditional human practices, such as el chinchorro (land-based trawler fishing practice) and el cambullón (commercial exchange between small local boats and foreign ships) can be considered intangible human goods. Thus, the beaches studied represented a connection between land and culture for centuries. The loss of a large part of the coastal features has thus resulted in part of the natural history of the island also being lost.

The idea of gaining land from the sea has been put into practice in numerous places and in many countries, including the Netherlands, Monaco, Dubai (Dubai Marina or Palm Island), Japan, New Zealand, Gibraltar, Chile (Valparaíso), Turkey (Istanbul), Indonesia and Singapore, among others. Similar studies to the present one have been conducted on some of these places in terms of quantifying urban growth in their coastal areas (Marfai et al., 2008; Smit et al., 2008; Kurt et al.,
2010; Nassar et al., 2014). Zhang et al. (2019) found that in Ningbo (a coastal city in China) construction land, i.e. urban/rural residential land, industrial and commercial areas, as well as other facilities, dominated in the period 1990-2005. However, this trend changed for 2005-2016, when agricultural use became dominant. Comber et al. (2016) analyzed land use changes on the coasts of England, Wales and Northern Ireland between 1965 and 2014, detecting a decline in defense land uses and an increase in urban and leisure land use, as well as woodland. On the other hand, Thanh Thoai and Dang (2019) studied the evolution over a 20 year period (1990-2010) of a coastline in the south of Vietnam. During this period, 2206 ha of coastal zone were lost to erosion, in which both natural and human factors intervened. Erosive losses were also observed by Aymara and Benseny (2016) in Miramar (Argentina) from 1888 to 2015 associated with urban-tourism development. In Spain, other similar investigations have been carried out, such as the work of Sanjosé et al. (2016) on the coastal evolution of the Cantabrian coast (northern Spain) in the period 1988-2014, in which they observed the retreat of the coastline. Manno et al. (2016) studied the evolution of coastline armouring along Spain's Andalusian coast during the period 1956-2010 when ports and coastal defense infrastructures (breakwaters, etc.) were created to avoid erosive losses and to expand the dry beach to benefit tourist and urban development at the expense of natural sedimentary transport. A general view of all these studies proves that changes in land use are dynamic in terms of adopting different trends.

The historical reconstruction of coastal areas can be used to understand their spatial variation over time and can provide keys to understand their function and current state (Douglas and Crowell, 2000; Botequilha Leita and Ahern (2002)). Studies of this type should be considered when management, protection or regional planning projects are being undertaken in order to develop a more sustainable urban fabric. In this regard, it should be taken into account that, in the period 
Table 7

Natural and cultural characteristics, land use and lost area of the central sector of the eastern coast of LPGC.

\begin{tabular}{|c|c|c|c|c|c|c|c|c|c|}
\hline & & DESCRIP & & & GEOLOGY & ECOLOGY & CULTURE & $\begin{array}{l}\text { LAND } \\
\text { USES }\end{array}$ & $\begin{array}{l}\text { LOST } \\
\text { AREA }\end{array}$ \\
\hline \multirow{4}{*}{ 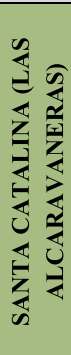 } & Location & Coordinates & Length & Beach & \multirow{4}{*}{$\begin{array}{l}\text { Part of the seaward } \\
\text { outlet of the extinct dune } \\
\text { fields of Guanarteme } \\
\text { Mixed composition } \\
\text { (organogenic-volcanic) } \\
\text { and fine grain size }\end{array}$} & \multirow{4}{*}{$\begin{array}{l}\text { Sparse and scarce } \\
\text { vegetation (halophile, } \\
\text { psammophile and } \\
\text { xerophile species), } \\
\text { with the most } \\
\text { significant being } \\
\text { Traganum moquinii } \\
\text { Varied and rich in } \\
\text { marine fauna species }\end{array}$} & \multirow{4}{*}{$\begin{array}{l}\text { Health tourism } \\
\text { due to the } \\
\text { beneficial } \\
\text { properties of the } \\
\text { water and climatic } \\
\text { and environmental } \\
\text { qualities } \\
\text { Hotels (Santa } \\
\text { Catalina, Metropol, } \\
\text { British Club) }\end{array}$} & \multirow[b]{4}{*}{$\begin{array}{l}\text { Agricultural } \\
\text { Defensive } \\
\text { Fishing } \\
\text { Residential } \\
\text { Commercial } \\
\text { Recreational }\end{array}$} & \multirow[b]{4}{*}{$55.2 \%$} \\
\hline & \multirow{2}{*}{$\begin{array}{l}\text { East } \\
\text { coast }\end{array}$} & $\begin{array}{l}28^{\circ} 08^{\prime} 09.12^{\prime \prime} \mathrm{N} \\
15^{\circ} 25^{\prime} 44.40^{\prime \prime} \mathrm{W}\end{array}$ & \multirow{2}{*}{$\begin{array}{l}1.9 \mathrm{~km} \\
\text { approx.. }\end{array}$} & \multirow[t]{2}{*}{ Sand } & & & & & \\
\hline & & $\begin{array}{l}28^{\circ} 07^{\prime} 07.77^{\prime \prime} \mathrm{N} \\
15^{\circ} 25^{\prime} 27.38^{\prime \prime} \mathrm{W}\end{array}$ & & & & & & & \\
\hline & & & & & & & & & \\
\hline \multirow{4}{*}{ 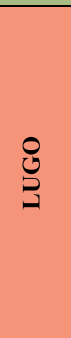 } & Location & Coordinates & Length & Beach & \multirow{4}{*}{$\begin{array}{l}\text { Phonolite base with fossil } \\
\text { marine deposits from the } \\
\text { Pleistocene } \\
\text { Strombus bubonius and } \\
\text { Thais haemastoma } \\
\text { (Linné) fossils } \\
\text { Conglomerates of } \\
\text { rounded basaltic pebbles } \\
\text { (upper level) }\end{array}$} & \multirow{4}{*}{$\begin{array}{l}\text { Sparse and scarce } \\
\text { vegetation (halophile, } \\
\text { psammophile and } \\
\text { xerophile species), } \\
\text { with the most } \\
\text { significant being } \\
\text { Traganum moquinii } \\
\text { Varied and rich in } \\
\text { marine fauna species }\end{array}$} & \multirow{4}{*}{$\begin{array}{l}\text { Residential and } \\
\text { commercial area }\end{array}$} & \multirow{4}{*}{$\begin{array}{c}\text { Fishing } \\
\text { Agricultural } \\
\text { Residential } \\
\text { Recreational }\end{array}$} & \multirow{4}{*}{$100 \%$} \\
\hline & $\begin{array}{l}\text { East } \\
\text { coast }\end{array}$ & $\begin{array}{l}28^{\circ} 07^{\prime} 25.27^{\prime \prime} \mathrm{N} \\
15^{\circ} 25^{\prime} 39.26^{\prime \prime} \mathrm{W}\end{array}$ & $\begin{array}{l}700 \mathrm{~m} \\
\text { approx. }\end{array}$ & Mixed & & & & & \\
\hline & & $\begin{array}{l}28^{\circ} 07^{\prime} 07.61^{\prime \prime} \mathrm{N} \\
15^{\circ} 25^{\prime} 25.35^{\prime \prime} \mathrm{W}\end{array}$ & & & & & & & \\
\hline & & & & & & & & & \\
\hline \multirow{4}{*}{ 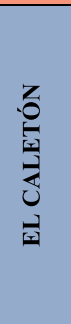 } & Location & Coordinates & Length & Beach & \multirow{4}{*}{$\begin{array}{l}\text { Phonolite base with } \\
\text { fossil marine deposits } \\
\text { from the Pleistocene. } \\
\text { Strombus bubonius and } \\
\text { Thais haemastoma } \\
\text { (Linné) fossils } \\
\text { Conglomerates of } \\
\text { rounded basaltic pebbles } \\
\text { (upper level) }\end{array}$} & \multirow{4}{*}{$\begin{array}{l}\text { Sparse and scarce } \\
\text { vegetation (halophile, } \\
\text { psammophile and } \\
\text { xerophile species), } \\
\text { with the most } \\
\text { significant being } \\
\text { Traganum moquinii } \\
\text { Varied and rich in } \\
\text { marine fauna species }\end{array}$} & \multirow{4}{*}{$\begin{array}{l}\text { Carpentries, } \\
\text { warehouses and } \\
\text { food industries } \\
\text { Windmills for the } \\
\text { production of } \\
\text { breadmaking flour } \\
\text { and gofio (toasted } \\
\text { cornmeal) }\end{array}$} & \multirow{4}{*}{$\begin{array}{c}\text { Fishing } \\
\text { Agricultural } \\
\text { Industrial } \\
\text { Residential } \\
\text { Commercial } \\
\text { Recreational }\end{array}$} & \multirow{4}{*}{$100 \%$} \\
\hline & East & $\begin{array}{l}28^{\circ} 07^{\prime} 07.77^{\prime \prime} \mathrm{N} \\
15^{\circ} 25^{\prime} 27.38^{\prime \prime} \mathrm{W} \\
\end{array}$ & & Mixed & & & & & \\
\hline & & $\begin{array}{l}28^{\circ} 07^{\prime} 07.77^{\prime \prime} \mathrm{N} \\
15^{\circ} 25^{\prime} 27.38^{\prime \prime} \mathrm{W} \\
\end{array}$ & approx. & & & & & & \\
\hline & \multicolumn{2}{|c|}{$\frac{3}{i} \cdot i$} & & & & & & & \\
\hline \multirow{4}{*}{$\sum_{\substack{1 \\
0}}^{\infty}$} & Location & Coordinates & Length & Beach & \multirow{4}{*}{$\begin{array}{l}\text { Phonolite base with } \\
\text { fossil marine deposits } \\
\text { from Pleistocene } \\
\text { Strombus bubonius and } \\
\text { Thais haemastoma } \\
\text { (Linné) fossils } \\
\text { Conglomerates of } \\
\text { rounded basaltic pebbles } \\
\text { (upper level) }\end{array}$} & \multirow{4}{*}{$\begin{array}{l}\text { Sparse and scarce } \\
\text { vegetation (halophile, } \\
\text { psammophile and } \\
\text { xerophile species), } \\
\text { with the most } \\
\text { significant being } \\
\text { Traganum moquinii } \\
\text { Varied and rich in } \\
\text { marine fauna species }\end{array}$} & \multirow{4}{*}{$\begin{array}{l}\text { Carpentries, } \\
\text { warehouses and } \\
\text { food industries } \\
\text { Buildings for } \\
\text { recreational and } \\
\text { social use }\end{array}$} & \multirow{4}{*}{$\begin{array}{c}\text { Fishing } \\
\text { Agricultural } \\
\text { Industrial } \\
\text { Residential } \\
\text { Commercial } \\
\text { Recreational }\end{array}$} & \multirow[b]{4}{*}{$100 \%$} \\
\hline & East & $\begin{array}{l}28^{\circ} 07^{\prime} 07.77^{\prime \prime} \mathrm{N} \\
15^{\circ} 25^{\prime} 27.38^{\prime \prime} \mathrm{W}\end{array}$ & $600 \mathrm{~m}$ & Mixed & & & & & \\
\hline & & $\begin{array}{l}28^{\circ} 07^{\prime} 07.77^{\prime \prime} \mathrm{N} \\
15^{\circ} 25^{\prime} 27.38^{\prime \prime} \mathrm{W}\end{array}$ & & & & & & & \\
\hline & $x=4$ & & & & & & & & \\
\hline \multirow{4}{*}{ 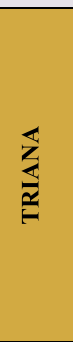 } & Location & Coordinates & Length & Beach & \multirow{4}{*}{$\begin{array}{l}\text { Phonolite base with } \\
\text { fossil marine deposits } \\
\text { from Pleistocene } \\
\text { Strombus bubonius and } \\
\text { Thais haemastoma } \\
\text { (Linné) fossils } \\
\text { Conglomerates of } \\
\text { rounded basaltic pebbles } \\
\text { (upper level) }\end{array}$} & \multirow{4}{*}{$\begin{array}{l}\text { Sparse and scarce } \\
\text { vegetation (halophile, } \\
\text { psammophile and } \\
\text { xerophile species) } \\
\text { Varied and rich in } \\
\text { marine fauna species }\end{array}$} & \multirow{4}{*}{$\begin{array}{l}\text { The first port of } \\
\text { the city (1811) } \\
\text { Santa Ana tower } \\
\text { (1574) located at } \\
\text { the end of the Las } \\
\text { Palmas wall at the } \\
\text { northern end of } \\
\text { the city }\end{array}$} & & \\
\hline & East & $\begin{array}{l}28^{\circ} 06^{\prime} 35.13^{\prime \prime} \mathrm{N} \\
15^{\circ} 24^{\prime} 59.92^{\prime \prime} \mathrm{W} \\
\end{array}$ & $740 \mathrm{~m}$ & Mixed & & & & & \\
\hline & & $\begin{array}{l}28^{\circ} 06^{\prime} 12.19^{\prime \prime} \mathrm{N} \\
15^{\circ} 24^{\prime} 47.96^{\prime \prime} \mathrm{W}\end{array}$ & approx.. & & & & & Fishing & \\
\hline & & & & & & & & $\begin{array}{l}\text { Defensive } \\
\text { Residential } \\
\text { Commercial } \\
\text { Recreational }\end{array}$ & $100 \%$ \\
\hline & Location & Coordinates & Length & Beach & Phonolite base with & Sparse and scarce & Commercial & & \\
\hline & $\begin{array}{l}\text { East } \\
\text { coast }\end{array}$ & $\begin{array}{l}28^{\circ} 06^{\prime} 10.34^{\prime \prime} \mathrm{N} \\
15^{\circ} 24^{\prime} 47.39^{\prime \prime} \mathrm{W}\end{array}$ & $\begin{array}{l}963 \mathrm{~m} \\
\text { approx. }\end{array}$ & $\begin{array}{c}\text { Pebble } \\
\text { s }\end{array}$ & $\begin{array}{l}\text { fossil marine deposits } \\
\text { from Pleistocene }\end{array}$ & $\begin{array}{l}\text { vegetation (halophile, } \\
\text { psammophile and }\end{array}$ & $\begin{array}{l}\text { facilities including } \\
\text { a market, }\end{array}$ & Fishing & \\
\hline$\underline{Z}$ & & $\begin{array}{l}28^{\circ} 05^{\prime} 40.65^{\prime \prime} \mathrm{N} \\
15^{\circ} 24^{\prime} 45.09^{\prime \prime} \mathrm{W} \\
\end{array}$ & & & Strombus bubonius and & xerophile species) & $\begin{array}{l}\text { fishmonger's, } \\
\text { butcher's etc }\end{array}$ & $\begin{array}{l}\text { Defensive } \\
\text { Residential }\end{array}$ & \\
\hline 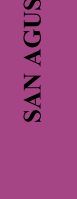 & & & & & $\begin{array}{l}\text { Thais haemastoma } \\
\text { (Linné) fossils } \\
\text { Conglomerates of } \\
\text { rounded basaltic pebbles } \\
\text { (upper level) }\end{array}$ & $\begin{array}{l}\text { Varied and rich in } \\
\text { marine fauna species }\end{array}$ & $\begin{array}{l}\text { and public } \\
\text { buildings }\end{array}$ & $\begin{array}{l}\text { Commercial } \\
\text { Industrial } \\
\text { Agricultural }\end{array}$ & $100 \%$ \\
\hline
\end{tabular}


Table 8

Natural and cultural characteristics, land use and lost area of the southern sector of the eastern coast of LPGC.

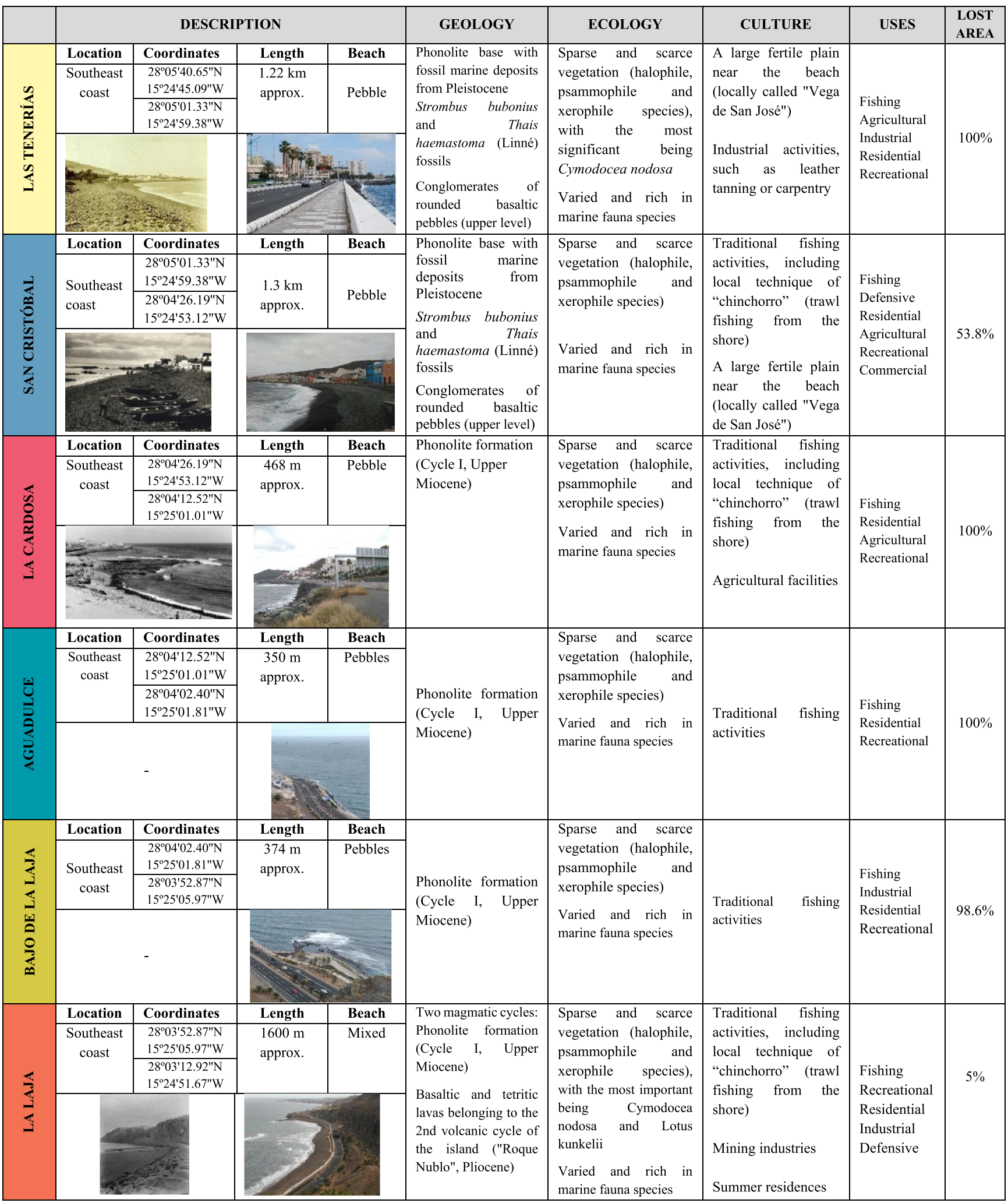

in which the transformation of the eastern coast of LPGC city took place (1960), the regulation of the coastal areas in Spain depended on the Port Laws (from 1880 to 1928), whose main objective was to meet the needs of navigation and shelter conditions for vessels and which paid no attention to non-port coastal areas (Torres, 2010). Spain's Law on Centers and Areas of National Tourist Interest of 1963 promoted tourism development on the Spanish coasts (Ariza et al., 2016), but had no impact on our area of study, since it was not an area of tourist attraction. 
It is only since promulgation of the Coastal Law of 1969 (and more directly the Coastal Law of 1988) that these spaces are considered areas to be preserved, through conservation of their ecosystems and stabilization of the coastlines (Ariza, 2011). Thus, prior to enactment of the first Coastal Law of 1969. there were no legal limits to urban plans that promoted the seaward urban growth of the city of LPGC. The three remaining beaches at that time (Alcaravaneras, San Cristóbal and La Laja) have been protected since then by that and later Coastal Laws and by municipal regulations based on that legislation. In accordance with these and the current municipal regulations on coasts and beaches (in force since 2013), in these three remaining beaches, conservation and improvement work has been carried out for public use and to guarantee the rational use of public space. Previously in this regard, in the 1990s, the Ministry of Environment carried out a regeneration action on La Laja beach, building a submerged dike and providing sand from nearby seabed (Ministry of Agriculture and Fisheries. Food and Environment, 2019). At present, through the City Council's 'Pacto por el Mar' (Ciudad de Mar 2014) initiative for the sustainable development of the LPGC coast, actions are underway aimed at sustainable coastline development ('Territorios Azules' project), promotion of the city's southernmost coastal area ('Cono Sur' project) and regeneration of the port isthmus area ('Sanapú-Istmo' project). The general goals of this wide-ranging initiative include improving water quality, reducing waste discharges at sea, and promoting sea-based renewable energies as well as marine and nautical sports tourism.

While many coastal areas of the planet have been considerably transformed and some may even have disappeared (as in our study area), it is clear that their restoration is, today, unfeasible, especially from the socio-economic point of view. Nonetheless, they retain an importance in their ability to sensitize society, hopefully making it more aware of the need to preserve and limit the damage that can be done and, especially, to avoid further negative environmental impacts in the future.

Likewise, this kind of study can be used to retrieve the environmental memory of a place enabling a knowledge and understanding of the relationship between the people that inhabited that place and its natural area (Hughes, 2006), as well as of the characteristics of the natural system (Santana Cordero et al., 2014).

Finally, this line of study can be the basis for the undertaking of new projects in which cultural activities are developed to help promote interest in natural heritage. Studies of this type can continuously be enriched with newly found materials and data.

\section{Conclusions}

This work is concerned with the reconstruction of the natural characteristics, cover and use of coastal land, and the rediscovery of traditions intrinsically associated with the territory in spaces that have disappeared as the result of recent human intervention. To achieve these objectives, a methodology was used which was based on historical, geographic and bibliographic sources.

The results of the study show that the vast majority of the natural and manmade elements which used to characterise the eastern coastline of Las Palmas de Gran Canaria city have progressively disappeared over the last 70 years. The analysis of the sources revealed the extension and previous use of lost beaches along the eastern coast of the city Las Palmas de Gran Canaria. In addition, the changes that have happened in recent decades were quantified.

Land use change has many implications, some of them related to the loss of human and natural assets. Such losses can disconnect a place from its past. Knowing an area's past by retrieving its historical characteristics is essential for planning its future development in a sustainable way. The integration of historical (natural and cultural) features can be extremely useful for future land change planning.

Working on the concept of lost natural heritage can open up new perspectives in historic reconstruction research, development and strategies. Through these, lessons from the past can be learned and applied to land management issues today. The results obtained from this type of study can also be used to develop original cultural strategies, educate new generations and provide visitors to the area with interesting and relevant information.

\section{Acknowledgements}

This work is a contribution to the CSO2013-43256-R and CSO201679673-R projects of the Spanish National Plan for $\mathrm{R}+\mathrm{D}+\mathrm{i}$ (innovation), co-financed with ERDF funds and a publication of the Unidad Océano $y$ Clima of the Universidad de Las Palmas de Gran Canaria, an R\&D\&i CSIC-associate unit. It was supported by a FPI-PhD grant from the ACIISI - Gobierno de Canarias, co-financed also with ERDF funds. It was completed while the first author was a PhD student in the IOCAG PhD Program in Oceanography and Global Change. The authors would like to thank Dr. José Mangas Vinuela for his support in the translation into English of some geological concepts.

\section{References}

Alcaraz Abellán, J., 1993. El Cabildo y la institucionalización del régimen franquista en Gran Canaria: Poder político y relaciones sociales entre 1936 y 1960. PhD thesis. Universidad de Las Palmas de Gran Canaria, 753 pp.

Archivo Histórico Nacional (A.H.H.), 1894. Proyecto de una explanada para urbanizar ganada al mar en las playas de Santa Catalina. File 24/1085. Ministerio Obras Públicas. Sección puertos [Grupo de Geografía Física y Medio Ambiente (ULPGC)].

Ariza, E., 2011. An analysis of beach management framework in Spain. Study case: the Catalonian coast. Journal of Coastal Conservation. 15, 445-455.

Ariza, E., Pons, F., Breton, F., 2016. Is "socio-ecological culture" really being taken into account to manage conflicts in the coastal zone? Inputs from Spanish Mediterranean beaches. Ocean Coast Manag. 134, 183-193.

Aymara, N., Benseny, G., 2016. Transformaciones litorales asociadas al desarrollo urbano turístico. El caso de Miramar (Argentina). Rev. Univ. Geogr. 25 (1), 93-113.

Bajocco, S., De Angelis, A., Perini, L., Ferrara, A., Salvati, L., 2012. The impact of land use/land cover changes on land degradation dynamics: a Mediterranean case study. Environ. Manag. 49, 980-989.

Banco de Datos de la Biodiversidad de Canarias (Gobierno de Canarias), 2016. Available in. http://www.biodiversidadcanarias.es/atlantis/common/index.jsf. (Accessed 1 June 2016).

Bator, J.P., 2009. Paraísos perdidos. Crónica gráfica de la transformación de la costa española. Saga, D.L, Barcelona, 206 pp.

Bochev Van der Burgh, L.M., Wijnberg, K.M., Hulscher, S.J.M.H., 2011. Decadal-scale morphologic variability of managed coastal dunes. Coast. Eng. 58 (9), 927-936.

Botequilha Leita, A., Ahern, J., 2002. Applying landscape ecological concepts and metrics in sustainable landscape planning. Landsc. Urban Plan. 59 (2), 65-93.

Bürgi, M., Gimmi, U., 2007. Three objectives of historical ecology: the case of litter collecting in Central European forests. Landsc. Ecol. 22, 77-87.

Caires, S., Swail, V.R., Xiaolan, L.W., 2006. Projection and analysis of extreme wave climate. J. Clim. 19, 5581-5605.

Centro Cartográfico y Fotográfico del Ejército del aire (CECAF), 1954. Cartographic and photographic Centre of Spanish Air force. Aerial Photogr. Las Palmas de Gran Canaria. Department of Geography (ULPGC).

Ciudad de Mar, 2014. Ayuntamiento de Las Palmas de Gran Canaria. Available in. http ://www.lpamar.com/home?locale=es. (Accessed 7 September 2019).

Cossío, J.M., 2014. La playa de Manolito. Unpublished. Las Palmas de Gran Canaria. 41 pp.

Comber, A.J., Davies, H., Pinder, D., Whittow, J.B., Woodhall, A., Johnson, S.C.M., 2016. Mapping coastal land use changes 1965-2014: methods for handling historical thematic data. Trans. Inst. Br. Geogr. 41 (4), 442-459.

Dabrio, C.J., Polo, M.D., 2015. Cambios del nivel del mar. Enseñanza las Ciencias Enseñanza Tierra: Rev. Asoc. Esp. Enseñanza las Ciencias Tierra 23 (2), 171-179.

Dawson, J.L., Smithers, S.G., 2010. Shoreline and beach volume change between 1967 and 2007 at raine island, great barrier reef, Australia. Glob. Planet. Chang. 72 (3), $141-154$.

Di Paola, G., Aucelli, P.P.C., Benassai, G., Iglesias, J., Rodriguez, G., Rosskopf, C.M., 2018. The assessment of the coastal vulnerability and exposure degree of gran Canaria island (Spain) with a focus on the coastal risk of las Canteras beach in las Palmas de Gran Canaria. J. Coast. Conserv. 22 (5), 1001-1015.

Douglas, B.C., Crowell, M., 2000. Long-term shoreline position prediction and error propagation. J. Coast. Res. 16 (1), 145-152.

El Banna, M., Frihy, O., 2009. Human-induced changes in the geomorphology of the northeastern coast of the Nile delta, Egypt. Geomorphology 107, 72-78.

Faggi, A., Dadon, J., 2011. Temporal and spatial changes in plant dune diversity in urban resorts. J. Coast. Conserv. 15, 585-594.

FEDAC (Fundación para la Etnografía y el Desarrollo de la Artesanía Canaria), 2015. Foundation for the Ethnography and development of canarian craft. Archivo fotográfico. Cabildo Insular de Gran Canaria. Available in. http://www.fedac.org. (Accessed 1 December 2016). 
Ferrer Valero, N., Hernández Calvento, L., Hernández Cordero, A.I., 2017. Human impacts quantification on the coastal landforms of gran Canaria island (canary islands). Geomorphology 286, 58-67.

Flor Blanco, G., Flor, G., Pando, L., 2013. Evolution of the Salinas-El Espartal and Xagó beach/dune systems in north-western Spain over recent decades: evidence for responses to natural processes and anthropogenic interventions. Geo Mar. Lett. 33, $143-157$.

Fogerty, J.E., 2005. Oral History: a guide to its creation and use. In: Egan, D., Howell, E. A. (Eds.), The Historical Ecology Handbook. Island Press, Washington, pp. 101-120.

García Romero, L., Hernández Cordero, A.I., Fernández Cabrera, E., Peña Alonso, C., Hernández Calvento, L., Pérez Chacón, E., 2016. Urban-touristic impacts on the Aeolian sedimentary systems of the Canary Islands: conflict between development and conservation. I.Stud. J. 11 (1), 91-112.

Gautreau, P., 2010. Rethinking the dynamics of woody vegetation in Uruguayan campos, 1800-2000. J. Hist. Geogr. 36 (2), 194-204.

GEVIC (Gran Enciclopedia Virtual Islas Canarias), 2016. Available in. http://www.gevic net/. (Accessed 1 June 2016).

Glavovic, B., Oppenheimer, M., Abd Elgawad, A., Cai, R., Cifuentes, M., Deconto, R., Ghosh, T., Hay, J., Hinkel, J., Isla, F., Magnan, A., Marzeion, B., Meyssignac, B., Sebesvari, Z., Van de Wal, R., Abe-Ouchi, A., Gupta, K., Pereira, J.J., 2019. sea level rise and implications for low lying islands, coasts and communities. In: Parry, M.L., Canziani, O.F., Palutikof, J.P., Van der Linden, P.J., Hanson, C.E. (Eds.), The Ocean and Cryosphere in a Changing Climate, vol. 4. Cambridge University Press, Cambridge, UK, pp. 687-716.

Gormsen, E., 1997. The impact of tourism on coastal areas. Geojournal 42 (1), 39-54.

Gran Canaria, 2018. Imágenes del ayer. Available in. https://es-es.facebook.com/Gr anCanaria. (Accessed 1 May 2018).

Grossinger, R.M., Striplen, C.J., Askevold, R.A., Brewster, E., Beller, E.E., 2007. Historical landscape ecology of an urbanized California valley: wetlands and woodlands in the Santa Clara Valley. Landsc. Ecol. 22 (1 Suppl. ment), 103-120.

Hay, J.E., 2013. Small island developing states: coastal systems, global change and sustainability. Sustain. Sci. 8 (3), 309-326.

Hemer A., M., Fan, Y., Mori, N., Semedo, Á., 2013. Projected changes wave climate from a multi-model ensemble. Nature Climate Change 3, 471-476.

Hepcan, S., Hepcan, C.C., Kilicaslani, C., Ozkan, M.B., Kocan, N., 2013. Analyzing landscape change and urban sprawl in a Mediterranean coastal landscape: a case study from Izmir, Turkey. J. Coast. Res. 29, 301-310.

Hernández Calvento, L., Monteiro Quintana, M.L., Pérez Chacón, E., García Romero, L. Santana Cordero, A., 2013. Cambios inducidos por actividades antrópicas en los procesos geomorfológicos eólicos de La Graciosa (islas Canarias). Una perspectiva histórica. Geotemas 14, 115-118.

Hoffman, M.T., Rohde, R.F., 2007. From pastoralism to tourism: the historical impact of changing land use practices in Namaqualand. J. Arid Environ. 70, 641-658.

Hughes, D.J., 2006. What Is Environmental History? Polity Press, Cambridge, 179 pp.

IDECanarias, 2018. Available in. www.idecanarias.es. (Accessed 1 June 2018).

Instituto Tecnológico Geominero de España (IGME), 1990. Mapa Geológico de España: Las Palmas de Gran Canaria and Santa Brígida.

IPCC, Intergovernmental Pannel for Climate Change, 2014. Climate change 2014: impacts, adaptation and vulnerability. Available in. http://www.ipcc.ch/report /ar5/wg2/. (Accessed 13 September 2019).

Jackson, N.L., Nordstrom, K.F., 2011. Aeolian sediment transport and landforms in managed coastal systems: a review. Aeolian Res. 3 (2), 181-196.

Johnson, J.M., Moore, L.J., Ells, K., Murray, B., Adams, P.N., Mackenzie, R.A., 2015. Recent shifts in coastline change and shoreline stabilization linked to storm climate change. Earth Surf. Process. Landforms 40, 569-585.

Kiss, T., Sipos, G., Kovács, F., 2009. Human impact on fixed sand dunes revealed by morphometric analysis. Earth Surf. Process. Landforms 34 (5), 700-711.

Kurt, S., Karaburun, A., Demirci, A., 2010. Coastline changes in istanbul between 1987 and 2007. Sci. Res. Essays 5 (19), 3009-3017.

Lambin, E.F., Meyfroidt, P., 2010. Land use transitions: socio-ecological feedback versus socio-economic change. Land Use Policy 27, 108-118.

Las Palmas Ayer y Hoy, 2018. Available in. https://es-es.facebook.com/GRAN-CANARIA -im\%C3\%A1genes-del-ayer-129963507207474/. (Accessed 1 May 2018).

Lin, J.C., 1996. Coastal modification due to human influence in southwestern Taiwan. Quat. Sci. Rev. 15, 895-900.

Machín Gil, H., Ruiz-Sánchez, J., 2006. Ensanche de Triana. Secundino Zuazo, 1962. Departamento de Urbanismo y Ordenación del Territorio, Las Palmas de Gran Canaria, $29 \mathrm{pp}$.

Machín Gil, H., 2006. San Cristóbal, barrio pesquero. Departamento urbanismo y ordenación del territorio, Las Palmas de Gran Canaria, 25 pp.

Malavasi, M., Santoro, R., Cutini, M., Acosta, A.T.R., Carranza, M.L., 2013. What has happened to coastal dunes in the last half century? A multitemporal coastal landscape analysis in Central Italy. Landsc. Urban Plan. 119 (1), 54-63.

Manno, G., Anfuso, G., Messina, E., Williams, A.T., Suffo, M., Liguori, V., 2016. Decadal evolution of coastline armouring along the Mediterranean Andalusia littoral (South of Spain). Ocean Coast Manag. 124, 84-99.

Marfai, M.A., Almohammad, H., Dey, S., Susanto, B., King, L., 2008. Coastal dynamic and shoreline mapping: multi-sources spatial data analysis in Semarang, Indonesia. Environ. Monit. Assess. 142, 297-308.

Martín Galán, F., 1980. La ciudad de Las Palmas: trama urbana, evolución, situación presente. In: Morales Padrón, F (coord), III Coloquio de Historia canario Americana (1978), 2. Cabildo de Gran Canaria, pp. 121-145.

Martín Galán, F., 2001. Las Palmas Ciudad y Puerto. Cinco siglos de evolución. Fundación Puertos de Las Palmas, Las Palmas de Gran Canaria, 524 pp.

Martín Galán, F., 2007. El mar, la Ciudad y el Urbanismo. Vivir el litoral en las ciudades históricas de Canarias. Port Authority of Santa Cruz de Tenerife, Port Authority of
Las Palmas and Fundación Puertos de Las Palmas, Las Palmas de Gran Canaria and Santa Cruz de Tenerife, 159 pp.

Martín Galán, F., 2008. Playas, urbanismo y turismo en ciudades litorales históricas de Canarias. Rev. Esc. Univ. Tur. Iriarte 0, 59-94.

Martín Galán, F., 2009. Islas, sol, barcos, hoteles y climatoterapia. El turismo en Las Palmas de Gran Canaria hasta la primera Guerra Mundial. Rev. Esc. Univ. Tur. Iriarte $1,143-174$.

Martínez, M.L., Intralawan, A., Vázquez, G., Pérez-Maqueo, O., Sutton, P., Landgrave, R., 2007. The coasts of our world: ecological, economic and social importance. Ecol. Econ. 63, 254-272.

McAllister, L.S., 2008. Reconstructing historical riparian conditions of two river basins in eastern Oregon, USA. Environ. Manag. 42, 412-425.

McLeman, R., Herold, S., Reljic, Z., Sawada, M., McKenney, D., 2010. GIS based modeling of drought and historical population change on the Canadian prairies. J. Hist. Geogr. 36 (1), 43-56.

Mimura, N., Nurse, L., McLean, R.F., Agard, J., Briguglio, L., Lefale, Payet R., Sem, G. 2007. Small islands. Climate change. Impacts, adaptation and vulnerability. In: Parry, M.L., Canziani, O.F., Palutikof, J.P., Van der Linden, P.J., Hanson, C.E. (Eds.), Contribution of Working Group II to the Fourth Assessment Report of the Intergovernmental Panel on Climate Change, 16. Cambridge University Press, Cambridge, UK, pp. 687-716.

Ministerio de Agricultura y Pesca, Alimentación y Medio Ambiente, 2019. Guía de Playas. Available in. https://sig.mapama.gob.es/guia-playas/. (Accessed 7 September 2019).

Nassar, A.K., Blackburn, G.A., Whyatt, J.D., 2014. Developing the desert: the pace and process of urban growth in Dubai. Computers,. Environ. Urban Syst. 45, 50-62.

Nordstrom, K.F., 1994. Beaches and dunes of human-altered coasts. Prog. Phys. Geogr.: Earth Environ. 18, 497-516.

Noreña Salto, T., Pérez García, J.M., 1992. Imperialismo europeo, despegue portuario y crecimiento económico en Las Palmas de Gran Canaria, 1882-1931, Las ciudades en la modernización de España: los decenios interseculares. In: García Delgado, J.L. (Coord), VIII Coloquio de Historia Contemporánea de España, pp. 461-474.

Ojeda Zújar, J., 2000. Métodos para el cálculo de la erosión costera. Revisión, tendencias y propuesta. Bol. Asoc. Geógr. Esp. (AGE) 30, 103-118.

Ouzts, E., 2007. Losing Our Natural Heritage: Development and Open Spaces Loss in North Carolina Environment. North Carolina Research \& Policy Center. Raleigh, NC, $29 \mathrm{pp}$.

Pérez Hernández, E., Hernández Calvento, L., 2017. Identificación y reconstrucción de características de tramos perdidos del litoral de Las Palmas de Gran Canaria (islas Canarias). Geotemas 17, 191-194.

Ponte Lira, C., Nobre Silva, A., Taborda, R., Freire de Andrade, C., 2016. Coastline evolution of Portuguese low-lying sandy coast in the last 50 years: an integrated approach. Earth Syst. Sci. Data 8 (1), 265-278.

Preston, J., Hurst, M.D., Mudd, S.M., Goodwin, G.C.H., Newton, A.J., Dugmore, A.J., 2018. Sediment accumulation in embayments controlled by bathymetric slope and wave energy: implications for beach formation and persistence. Earth Surf. Process. Landforms 43, 2421-2434.

Recuerdos de Gran Canaria, 2018. Available in. https://es-es.facebook.com/Recuerdo sDeGranCanaria/. (Accessed 1 May 2018).

Reglamento municipal de costas y playas del término municipal de Las Palmas de Gran Canaria, 2013. Boletín Oficial de la Provincia de Las Palmas. Número 103, miércoles 14 de agosto de 2013. Available in. http://www.lpamar.com/somos-ciudad-de-mar/ reglamento-municipal-de-costas-y-playas.-protocolos-varios/. (Accessed 8 September 2019).

Robinson, A.H., Sale, R.D., Morrison, J.L., Muehrcke, P.C., 1987. Elementos de cartografía. Omega, Barcelona, 543 pp.

Roig Munar, F.X., Pons, G.X., Martín Prieto, J.A., Rodríguez Pérez, A., Mir Gual, M., 2012. Análisis espacio-temporal (1956-2004) de los sistemas dunares de Menorca (Islas Baleares) mediante variables geoambientales de uso y gestión. Bol. Asoc. Geógr. Esp. 58, 381-403.

Sanjosé, J.J., Serrano, E., Berenguer, F., González, J.J., Gómez, M., González, M., Guerrero, M., 2016. Evolución histórica y actual de la línea de costa en la playa de Somo (Cantabria), mediante el empleo de la fotogrametría aérea y escáner láser terrestre. Cuaternario Geomorfol. 30 (1), 119-130.

Santana Cordero, A.M., Monteiro Quintana, M.L., Hernández Calvento, L., 2014. Reconstructing the environmental conditions of extinct coastal dune systems using historical sources: the case of the Guanarteme dune field (Canary Islands, Spain). J. Coast. Conserv. 18, 323-337.

Santana Cordero, A.M., Monteiro Quintana, M.L., Hernández Calvento, L., 2016. Reconstruction of the land uses that led to the termination of an arid coastal dune system: the case of the Guanarteme dune system (Canary Islands, Spain), 1834-2012. Land Use Policy 55, 73-85.

Santana Cordero, A.M., Bürgi, M., Hersperger, A.M., Hernández Calvento, L., Monteiro Quintana, M.L., 2017. A century of change in coastal sedimentary landscapes in the Canary Islands (Spain) - change, processes, and driving forces. Land Use Policy 68, 107-116.

Schnack, E., Pousa, J.L., Isla, F.I., 2002. Las fluctuaciones del nivel del mar durante el Cuaternario. Museo 16 (3), 79-87.

Sloan, S., 2008. Oral history and Hurricane katrine: reflections on shouts and silences. Oral Hist. Rev. 35 (2), 176-186.

Smit, F., Mocke, G.P., Giarrusso, C.C., Baranasuriya, P.W., 2008. Coastal modelling of the dubai coastline with emphasis on morphological model validation. PIANCCOPEDEC: VII Int. Conf. Coast. Port Eng. Dev. Ctries. Best Pract. Coast. Environ. Dubai vol. 71, 1-20.

Stanica, A., Ungureanu, V.U., 2010. Understanding coastal morphology and sedimentology. Terre Environnement 88, 105-111. 
Stäuble, S., Martin, S., Reynard, E., 2008. Historical mapping for landscape reconstruction: examples from the canton of valais (Switzerland). In: Mountain mapping and visualisation. Proc. 6th ICA Mt. Cartogr. Workshop, Lenk, Switzerland 211-217.

Stein, E.D., Dark, S., Longcore, T., Grossinger, R., Hall, N., Beland, M., 2010. Historica ecology as a tool for assessing landscape change and informing wetland restoration priorities. Wetlands 30, 589-601.

Thanh Thoai, D., Dang, A.N., 2019. Analysis of coastline change in relation to

meteorological conditions and human activities in Ca mau cape, Viet Nam. Ocean Coast Manag. 171, 56-65.
Torres, F.J., 2010. Cuarenta años de leyes de costas en España (1969-2009). Invest. Geográficas 52, 167-198.

Tous, J., Herrera, A., 1995. Las Palmas de Gran Canaria a través de la cartografía: 1588-1899. Cabildo Insular de Gran Canaria, Las Palmas de Gran Canaria, p. 205.

Zhang, C., Zhong, S., Wang, X., Shen, L., Liu, L., Liu, Y., 2019. Land use change in coastal cities during the rapid urbanization period from 1990 to 2016: a case study in Ningbo city, China. Sustainability 11, 2122. 